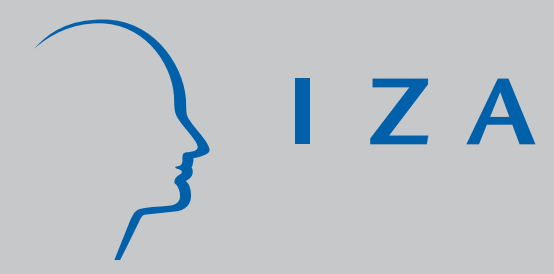

IZADP No. 1714

\title{
A Model of Foreign-Born Transfers: Evidence from Canadian Micro Data
}

Don J . DeVoretz

Florin P. Vadean

August 2005 


\title{
A Model of Foreign-Born Transfers: Evidence from Canadian Micro Data
}

\author{
Don J. DeVoretz \\ RIIM, Simon Fraser University \\ and IZA Bonn \\ Florin P. Vadean \\ HWWA Hamburg \\ and RIIM, Simon Fraser University
}

Discussion Paper No. 1714

August 2005

\author{
IZA \\ P.O. Box 7240 \\ 53072 Bonn \\ Germany \\ Email: iza@iza.org
}

Phone: +49-228-3894-0

Fax: +49-228-3894-180

\begin{abstract}
Any opinions expressed here are those of the author(s) and not those of the institute. Research disseminated by IZA may include views on policy, but the institute itself takes no institutional policy positions.

The Institute for the Study of Labor (IZA) in Bonn is a local and virtual international research center and a place of communication between science, politics and business. IZA is an independent nonprofit company supported by Deutsche Post World Net. The center is associated with the University of Bonn and offers a stimulating research environment through its research networks, research support, and visitors and doctoral programs. IZA engages in (i) original and internationally competitive research in all fields of labor economics, (ii) development of policy concepts, and (iii) dissemination of research results and concepts to the interested public.
\end{abstract}

IZA Discussion Papers often represent preliminary work and are circulated to encourage discussion. Citation of such a paper should account for its provisional character. A revised version may be available directly from the author. 
IZA Discussion Paper No. 1714

August 2005

\section{ABSTRACT}

\section{A Model of Foreign-Born Transfers: Evidence from Canadian Micro Data*}

This paper models financial transfers outside the household for both the Canadian-born and foreign-born Canadian populations in a traditional expenditure framework. Using survey data we estimate transfer functions as part of a larger expenditure system and calculate Engel elasticities for remittances by both the Canadian and foreign-born populations. We conclude that transfers outside the household are a normal good for recent Asian immigrants and a luxury good for all other immigrants and Canadians. Immigrant transfers upon arrival are greater than Canadian-born transfers indicating a strong entry effect. Assimilation or convergence to the Canadian-born norm over time is however very slow. We also find evidence of negative foreign-born transfers as sending country households remit to Canadian immigrant households. Finally, all foreign-born groups generally consider remittances to charitable organizations a greater necessity than inter-household transfers.

JEL Classification: J63, O15

Keywords: immigration, remittances

Corresponding author:

Florin P. Vadean

Hamburg Institute of World Economics (HWWA)

Neuer Jungfernstieg 21

D-20347 Hamburg

Germany

Email: Florin.Vadean@hwwa.de

\footnotetext{
* Support from RIIM, Simon Fraser University, Friedrich Naumann Foundation and IZA, Bonn are noted with appreciation. A preliminary version of this paper was presented at Migration and Development-Working with the Diaspora Seminar, ILO Berlin May, 2004.
} 


\section{Introduction}

The role of remittances in the traditional economic development literature is substantial but largely focused on the size and potential impact of migrant transfers in the immigrant sending country (Straubhaar and Vadean, 2005). In a more modern setting, remittances have been more explicitly linked to the motivations to remit by the Diaspora communities' residents in major immigrant receiving regions (Aescobar, 2004 and Adams, 2004, 1998). This paper expands on this literature by assessing the motivations of Canadian immigrant households to remit within an explicit immigration policy environment. In short, we ask what are the motivations to remit by the large and permanent legal Diaspora communities in Canada? By answering this question we will provide a contrasting example to the existing studies which concentrate on the motivations to remit from temporary and perhaps illegal Diaspora communities (e.g. Mexicans in the U.S.) or from more permanent refugee communities in Europe.

The foreign-born Canadian resident population studied in this paper is large (5 million), diverse and growing (250,000 per year). In addition, the vast majority of these foreign-born residents are admitted to Canada on a permanent basis (96\%) and often accompanied by their immediate families. ${ }^{1}$ Finally, Canada's family reunification policy permits sponsorship of parents and grandparents with no explicit waiting period thus potentially blunting the motivation to remit. $^{2}$ Under these conditions of a guaranteed permanent residence for the nuclear immigrant household and the prospect of relatively expeditious family reunification as well as quick ascension to citizenship we test the motivation to remit in the Canadian context with a formal expenditure model. ${ }^{3}$

\section{Literature Review}

Cox (1987) argues that there exist two main motivations for private income transfers: altruism and exchange. Becker (1974) earlier stated that an income transfer was a benevolent act which promoted well-being and equality across the extended family. In a less altruistic version of the

\footnotetext{
${ }^{1}$ Permanent Canadian immigrants upon admission are permitted to immediately bring with them their spouse and any minor (under age 19) children. In 2001, only 198,640 foreign-born residents were non-permanent out of a total of 5.7 million total foreign-born residents (Statistics Canada, 2001).

${ }^{2}$ There is however a financial constraint on family reunification. Before an immigrant can sponsor a relative, the sponsor must demonstrate financial viability. This is accomplished by demonstrating that the immigrant household's income from non-government transfers exceeds the poverty line (LICO) in the city of residence. This value circa 2005 is approximately $\$ 40,000$ in urban Canada and beyond the reach of the vast majority of recent Canadian immigrants.

${ }^{3}$ Over 75\% of Canada’s foreign-born population had ascended to citizenship in 1996 (DeVoretz and Pivnenko, 2004).
} 
exchange model proposed by Bernheim, Shleifer and Summers (1985), transfers are motivated by the prospect of a later exchange for services by extended family members.

Lucas and Stark (1985) more broadly addressed the range of immigrant transfer motives and classified immigrant intentions to remit as those motivated by pure altruism, selfinterest and tempered altruism or enlightened self-interest. The pure self-interest motivation includes an aspiration to inherit and a desire to invest in assets at home, especially when the immigrant intends to return to his/her home country. If remittances occur as the result of a beneficial contractual agreement between the migrant and home, they are termed by Lucas and Stark (1985) as acts of "tempered altruism or enlightened self-interest”. One example of this case is when remittances are in fact a repayment to the migrant's family for a previous educational investment in the immigrant. Migrants may also transfer part of their income home because of an implied coinsurance contract between the them and the family. Under this system the motivation to remit is to secure the help of the family when the need arises (Stark 1991).

Limited empirical evidence tends to support some of the above hypotheses. Cox and Rank (1992) find that empirical patterns for inter-vivo transfers are more consistent with exchange than altruism. ${ }^{4}$ Cox (1987) reached a similar conclusion. Duraisamy et al. (2000) find a strong positive association between family ties and remittances and argue that this is indirect evidence in support of the altruism hypothesis.

Other evidence reports a link between remittances, intention to return home and investment in human and physical capital. Ahlburg et al. (1998) found very little evidence to support the assumption that immigrants who plan to return home embody significant human capital. However, they discovered that those who plan to return remit significantly more and also accumulate far more physical capital at home than those who do not plan to return. Brown (1994) finds that more funds are remitted when they are intended for savings and investment rather than when they are used for family consumption.

Shamsuddin and DeVoretz (1998) have analysed the more general question of wealth accumulation of immigrant and non-immigrant households in Canada. They have found a strong transfer (bequest) motive for the Canadian foreign born and a bias toward home ownership in the investment portfolios. ${ }^{5}$ They note that these two phenomena should act as a substitute for transfers outside the foreign-born household.

\footnotetext{
${ }^{4}$ Inter vivo transfers are those between living persons (vs. bequests).

${ }^{5}$ Diduukh (2002) also notes this possible home ownership-remittance substitution.
} 
This diverse sampling of the modern remittance literature suggests a complex set of motives to remit. For purposes of this paper several points emerge. First, the legal status of resident immigrants (permanent, temporary, illegal) should condition the size of the household transfers. Secondly, family reunification policies or the presence of family members at home or away will affect the flow of remittances. Also, remittances should appear as substitutes for household savings, wealth accumulation and home ownership for the foreign-born household. We will incorporate these features in the model developed below.

\section{Model}

This section presents an utility maximisation model which describes the conditions under which positive, negative or null financial household transfers arise. Under a multi-period framework (four stage model) changes in household composition (spouse at home or away), family reunification, altered immigrant status (temporary or permanent) and the possibility of intermittent return migration all will affect the size and direction of transfers. We theorise that household members derive utility from consumption and social relations with other household members, relatives left behind and membership in social/religious groups. Thus, we distinguish between two kinds of transfers: transfers to persons outside the household and charity donations, that denote group membership.

\section{Stage I}

In stage $I$ the $\left(\mathrm{i}^{\mathrm{th}}\right)$ household consists of one individual resident in country (B) with a temporary visa $\left(\mathrm{I}_{\mathrm{t}}\right)$ with no dependents abroad $(\mathrm{F}(0))$ in country $(\mathrm{A}) .^{6}$ The $\left(\mathrm{i}^{\text {th }}\right)$ household's utility function is given as:

$$
U_{i}^{B}=\left[\left(Y_{i}-S_{i}\right), T_{i}, C D_{i}, F, I_{s}\right]
$$

where:

$U_{i}^{B}$ equals total household utility of the $\left(\mathrm{i}^{\mathrm{th}}\right)$ household resident in country (B);

$\left(Y_{i}-S_{i}\right)$ equals home consumption or income $\left(Y_{i}\right)$ minus domestic savings $\left(S_{i}\right)$ by the $\left(\mathrm{i}^{\text {th }}\right)$ household in country (B);

$T_{i}$ equals financial transfers to persons household by the $\left(\mathrm{i}^{\text {th }}\right)$ household in country (B);

$C D_{i}$ equals financial transfers to charity by the $\left(\mathrm{i}^{\text {th }}\right)$ household in country (B);

$F$ equals the number of close relatives resident in country (A);

\footnotetext{
${ }^{6}$ These dependents include a possible spouse or child and of course parents, grandparents or minor siblings.
} 
$I_{s}$ equals $\left(\mathrm{i}^{\text {th }}\right)$ immigrant's status: temporary $\left(I_{t}\right)$ permanent $\left(I_{p}\right)$ or citizen $\left(I_{c}\right)$ in country (B);

$T_{i}+C D_{i}$ equals $S_{i}$; i.e. no borrowing.

Now, we will present the case of a temporary immigrant resident in country (B) with zero foreign dependents generating zero transfers to households (Case A) or positive transfers to households (Case B).

Stage I, Case A: $T=0$ (no transfers)

If the one person household resident in country (B) maximises his utility $\left(U_{i}^{B}\right)$ with a budget constraint (eq. 2.1) and a leisure constraint (eq. 2.2) we can solve for the equilibrium transfer condition (eq. 3) or

$$
U_{i}^{B}=\left[\left(Y_{i}-S_{i}\right), T_{i}, C D_{i}, F(0), I_{t}\right]
$$

subject to:

$$
\begin{aligned}
& Y_{i}=(W \times w) \text { and } \\
& W=\left(H_{\mathrm{i}}-L_{\mathrm{i}}\right)
\end{aligned}
$$

where (W) equals number of hours worked, w equals the given wage, $H_{i}=24$ and $\left(\mathrm{L}_{\mathrm{i}}\right)$ equals number of hours of leisure and

$$
\left(Y_{i}-S_{i}\right)=\phi\left(p_{i} \times x_{i}\right)
$$

or income $\left(\mathrm{Y}_{\mathrm{i}}\right)$ minus savings $\left(\mathrm{S}_{\mathrm{i}}\right)$ equals total expenditures $\left(\phi\left(p_{i} \times x_{i}\right)\right)$ of the $\left(\mathrm{i}^{\text {th }}\right)$ household.

Now differentiate (2) with respect to first $\left(\mathrm{Y}_{\mathrm{i}}-\mathrm{S}_{\mathrm{i}}\right)$ and then $\left(\mathrm{T}_{\mathrm{i}}\right)$ and the first order conditions yield

$$
\frac{\delta U_{i}^{B}}{\delta\left(Y_{i}-S_{i}\right)}=\frac{\delta U_{i}^{B}}{\delta T_{i}}
$$

Or household utility is now maximised if the marginal utility of a remitted dollar $\delta T_{i}$ equals the marginal utility derived from one more unit of home consumption $\delta\left(Y_{i}-S_{i}\right)$. Thus, if there is only one member in the household and if the relative price for all consumption goods is cheaper in country (B) then transfers to home country (A) to purchase goods is zero.

In Stage I, with all conditions similar to those outlined above for (Case A) except a change in relative goods prices and the presence of a relative in country (B), positive transfers could be generated. 
Stage I, Case B: $T_{i}>0$ (positive transfers to persons)

If there is at least one good which is a non-tradable (e.g. housing) which is cheaper in the immigrant's sending country (A) then transfers will be positive. This arises as one dollar is transferred from consumption in country (B) or $\delta\left(Y_{i}-S_{i}\right)$ to country (A) to restore the equilibrium conditions in eq. 2.4 .

\section{Stage II}

In Stage II, the head of household ages and becomes married (with or without children). However, the head of household who is resident in country (B) still holds a temporary visa which does not permit reunification with his or her spouse. Under this condition $F(>0)$, i.e. the spouse lives in country (A) and the head of household lives in country (B). Now it is possible to generate either positive or negative transfers.

Stage II, Cases A and B: T>0 or $T<0$

Thus, if there exists a two member household and if the relative price for at least one nontradable consumption good in their joint utility function is cheaper in country (B), then remittances are negative $(\mathrm{T}<0)$ as money is transferred from country (A) to (B). ${ }^{7}$ In the opposite case where at least one non-tradable consumption good in their joint utility function is cheaper in country (A) then transfers are positive ( $>0$ ) from country (B) to (A).

\section{Stage III}

Stage III, Case A: certain reunification

In Stage III we permit two possible cases. In (Case A) the head of household in country (B) holds now a permanent visa $\left(\mathrm{I}_{\mathrm{p}}\right)$ or citizenship. Under this condition and given that his/her dependents initially live in country (A) or F (>0), the spouse and children (or parents) could now migrate to country (B). If reunification occurs then we revert to (Case A) or (Case B) under Stage I if both spouses have identical tastes. If the reunited spouse arrives in country (B) with a different set of tastes than the head of household (i.e. the original immigrant) then the potentially different set of relative prices between countries (A) and (B) could affect the direction of the now reunited household's transfers. For example, if the reunited household member's (spouse 2) consumption bundle includes a non-tradable good only available in country (A), (spouse 2) transfers money to country (A) and the other spouse would not.

\footnotetext{
${ }^{7}$ We assume that all tradables are competitively traded and prices are equalized.
} 
Stage III, Case B: uncertain reunification

Stage III is characterised by the spouse's possession of a permanent resident visa which allows reunification and the choice set now becomes even more complicated than that implied by the above paragraph. If the costs of the consumption set for both the spouse and any other dependent(s) resident in country (A) are cheaper than the costs of an identical consumption set in country (B) then the rational action of the household members is to decide to stay separated, if the households members derive no additional utility from living together. Thus, the spouse in country (B) should increase the level of transfers from (B) to (A) up to the net difference in cost of purchasing the desired consumption bundle between countries (A) and (B). In other words eq. 3 will determine if the spouse migrates to country (B) when LHS is greater than RHS or vice versa.

$$
\frac{\delta U}{\delta T} \times \frac{\delta T}{\delta F}>\text { or }<\frac{\delta U}{\delta F} \times \frac{\delta F}{\delta T}
$$

If the RHS exceeds the LHS than an increase in transfers ( $\delta T$ ) reduces the potential number of reunited family members $(\delta \mathrm{F})$ and in turn raises utility more than the prospect of increasing the number of united family members (and reducing transfers) will raise the household's utility level.

\section{Stage IV}

As we assumed above, households can derive utility not only from relations between relatives, but from membership in a social/religious group as well. Therefore, households can transfer funds to a charity. ${ }^{8}$ We argue that households can specialise either in transfers to persons or charitable donations or both. Below we briefly describe the motivations for charitable donations.

Stage IV, Case A: no charitable donations $(C D=0)$

If the household perceives no utility gain from being a member of a social/religious group, no charitable donations will be made, since $\delta U_{i} / \delta C D_{i}=0$.

Stage IV, Case B: positive charitable donations (CD>0)

When group membership yields utility, this implies that $\delta U_{i} / \delta C D_{i}>0$. In this case the choice becomes at the margin:

\footnotetext{
${ }^{8}$ The latest assuring the membership status.
} 


$$
\frac{\delta U_{i}}{\delta C D_{i}}>\text { or }<\frac{\delta U_{i}}{\delta T_{i}} \text { and } \frac{\delta U_{i}}{\delta C D_{i}}>\text { or }<\frac{\delta U_{i}}{\delta\left(Y_{i}-S_{i}\right)}
$$

If the LHS is greater than the RHS, i.e. the marginal utility charity derived from donations is greater than the marginal utility derived from transfers to relatives, and if this is simultaneously greater than the marginal utility derived from household consumption, positive charitable donations will be made. These donations will continue until $\delta U_{i} / \delta C D_{i}=\delta U_{i} / \delta T_{i}=\delta U_{i} / \delta\left(Y_{i}-S_{i}\right)$.

\section{Data and Descriptive Statistics}

The data sets used for this analysis with their respective sample sizes are the $1992(9,492)$ and 1996 (10,417) Family Expenditure Surveys (FAMEX), Income Statistics Division, Statistics Canada. Data where collected by means of filling out a detailed questionnaire during one or several interviews. Thus, income, expenditures and transfers data in the surveys are selfreported.

The focus of the empirical portion of this study is to investigate possible differential patterns of private transfers by Canadian-born and foreign-born households. We will use the Canadian-born population as our reference group since presumably they have no immediate attachments abroad. The research period 1992 to 1996 is of interest because it encompasses a dynamic period of expanding Canadian immigration inflows which dramatically shifted to Asian source countries and thus may effect the size and distribution of foreign-born transfers. ${ }^{9}$

These surveys, while extensive, have certain shortcomings. The 1992 survey includes a variable indicating the immigration year arrival for the foreign-born population, while the 1996 survey does not report this variable. We run the main analysis with pooled data for the 1992 and 1996 surveys. However, when controlling for time spent since immigration we use the 1992 survey only.

We will focus on households over their normal economic life and will limit our sample to those households whose head is older than 25. Only observations with positive and non-zero income, total expenditures and total transfers were kept in the regressions. ${ }^{10}$ Observations with negative expenditures for the different expenditure groups were excluded. Other observations with “masked” or "non-stated” responses (i.e. education, region of residence, country of birth etc.) were excluded as well. In addition, the head of household is

\footnotetext{
${ }^{9}$ In 196875 percent of Canadian immigrants came from Western Europe and North America, by 199225 percent came from these sources.
} 
chosen as the highest income earner. ${ }^{11}$ This definition of the household head will allow us to define a foreign-born (Canadian-born) household as one in which the highest earner is foreign-born (Canadian-born). The data from the pooled 1992 and 1996 surveys, given the above screening yields 16,318 surveyed households.

\section{Demographic, Income and Transfer Variables}

Data used in this study does not allow us to differentiate between transfers sent inside or outside Canada. However, we can differentiate between transfers made to persons and transfers to charity. An inspection of the actual transfer data indicates that many households specialise in the destination of their transferred funds. Specifically, 11 percent of the households transfer money exclusively to charitable organisations while over 18 percent transfer money only to persons and the remaining 71 percent of the sample transfer to both individuals and charitable groups. We hypothesise that charitable remittances should respond differently to household income since these donations are tax deductible and do not imply a contractual motive to extended family members.

Table 1: Some Descriptive Data by Population for the 1992 and 1996 surveys (mean values) Variable

Population Group

\begin{tabular}{lcccccccc} 
& \multicolumn{2}{c}{ Canadian } & \multicolumn{2}{c}{ N.Am\&W.Eu. } & S\&E Europ. & \multicolumn{2}{c}{ Ch.,Asian\&Oc. } \\
\cline { 2 - 10 } & $\mathbf{1 9 9 2}$ & $\mathbf{1 9 9 6}$ & $\mathbf{1 9 9 2}$ & $\mathbf{1 9 9 6}$ & $\mathbf{1 9 9 2}$ & $\mathbf{1 9 9 6}$ & $\mathbf{1 9 9 2}$ & $\mathbf{1 9 9 6}$ \\
\hline Woman as HH head & 0.43 & 0.45 & 0.42 & 0.46 & 0.31 & 0.40 & 0.31 & 0.40 \\
Age of HH head & 47.85 & 48.42 & 55.13 & 54.79 & 53.41 & 54.70 & 45.86 & 44.83 \\
Years since immigration & n.a. & n.a. & 31.52 & n.a. & 28.89 & n.a. & 13.88 & n.a. \\
Education & 2.74 & 2.93 & 3.09 & 3.05 & 2.39 & 2.47 & 3.30 & 3.51 \\
HH size & 2.61 & 2.54 & 2.41 & 2.35 & 2.75 & 2.74 & 3.31 & 3.49 \\
Home ownership & 0.64 & 0.66 & 0.68 & 0.69 & 0.76 & 0.75 & 0.56 & 0.71 \\
\hline HH income after taxes & 38,382 & 40,012 & 38,887 & 41,435 & 36,905 & 39,535 & 40,831 & 45,156 \\
Income per HH member & 14,695 & 15,769 & 16,136 & 17,595 & 13,425 & 14,403 & 12,332 & 12,953 \\
Net change in assets & 2,014 & 3,839 & 2,048 & 4,500 & 1,581 & 2,334 & 2,623 & 2,877 \\
Transfers to persons & 1,177 & 1,352 & 1,861 & 1,855 & 1,455 & 1,875 & 1,402 & 1,369 \\
Transfers to charity & 370 & 397 & 645 & 588 & 339 & 407 & 393 & 381 \\
\hline Observations & 6,893 & 7,077 & 545 & 631 & 289 & 343 & 196 & 344 \\
\hline Soln
\end{tabular}

Source: Authors' calculations; Family Expenditures Survey 1992 and 1996, Statistics Canada.

Notes: Education levels are $1=$ less than 9 years, $2=$ some or completed secondary, $3=$ some post-secondary, $4=$ Post secondary degree, 5 = University degree; Monetary values in 1992 dollars

Table 1 reports some descriptive statistics by birth status for the two survey years we included in our analysis: 1992 and 1996. The data only allow us to distinguish between Canadian-born and four foreign-born groups: North American and West European, South and East European,

\footnotetext{
${ }^{10}$ Less than 10 percent of the households did not make any transfers to persons or charity, thus minimizing the possibility of a self-selection bias.
} 
China, Asia and Oceania, and Others and Non-Stated. We excluded the last foreign-born group from our analysis, regarding it as being to heterogeneous.

Table 1 highlights the dramatic shift in Canadian immigration by source country from non-Asian to Asian countries between 1992-1996. Thus, heterogeneity arises in the foreign born population since Asian immigrants are younger, contain more males and have a significantly shorter immigration history in Canada than the remaining foreign-born groups. Also, Asian immigrant heads of households are better educated than the other foreign-born groups. However, Asians live in larger families and thus report a lower income per household member than other immigrant groups. As a consequence Asian immigrants remitted in absolute values the lowest amounts either to other households or charity. In contrast the group with the highest absolute remittances, both to persons and charity, are the North American and West European immigrant households. They remitted about 35 percent more than the Asian immigrants in 1996, but had as well a 35 percent higher income per household member.

Table 1 reports similarities in the patterns of transfers as a percentage of income per household. For example, regardless of foreign-born status households transferred about 1 percent of their income as charitable donations. In contrast, their transfers to persons varied by place of birth. Canadian and Asian immigrant households remitted about 3 percent of their income, while North American and West European and South and East European immigrant households remitted 4.5 percent of their income.

We now turn to a more in depth analysis of the household transfer data in two particular areas which will support out earlier model development and ultimately condition our tests.

First, a preliminary analysis of the data indicates that the mean values for remittances are dominated by a limited number of households. Figure 1 plots the cumulative rank against the cumulative share of transfers by all households who made a positive remittance in 1992 and $1996 .^{12}$ We can observe that 30 percent of the households remitted 80 percent of all remittances. The remaining 70 percent of the households remitted only 20 percent of the observed transfers in our pooled 1992/1996 sample. The Gini coefficient thus, assumed a high value of 0.66. Households, regardless of their foreign-born status, revealed a near identical distribution pattern which indicated that a few donate most of the observed transfers. We now ask how does this distribution compare with the distribution of household after-tax income,

\footnotetext{
${ }^{11}$ We assume that the highest earner is the person who determines the household's expenditure patterns.

${ }^{12}$ We omitted zero values to calculate this Gini calculation which is thus a lower bound estimate of the true degree of inequality.
} 
that presumably determines the ability to remit? Figure 1 reports a much more equally distributed size distribution of income (Lorenz curve) with a calculated Gini equal to 0.31 with the highest 30 percent of earners receiving about 60 percent of total population income.

Figure 1: Lorenz curves for Income and Transfers

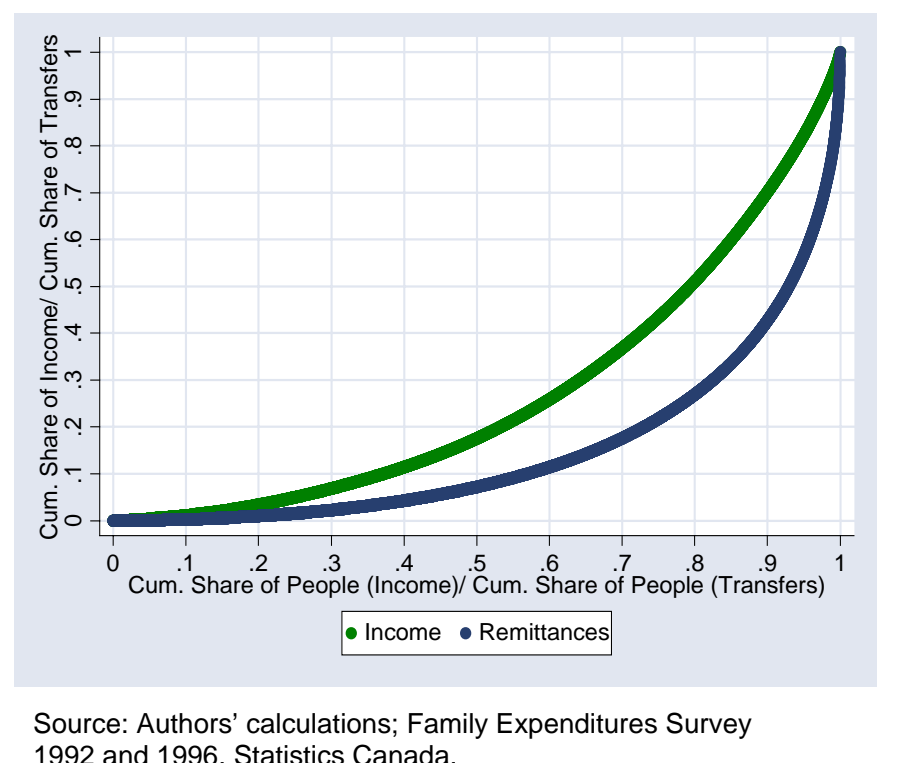

Transfers Received

Our model predicted two polar cases and one intermediate case of immigrant household transfers. ${ }^{13}$ To confirm the existence of these cases we report three empirical cases derived from our data set to illustrate these classifications. First, we present the case of the households that have positive remittances to persons outside the household. Next, we present the second case where households receive remittances and then we analyse the more typical case where the households receive funds, send funds or both. ${ }^{14}$

We screened the data as earlier, with the single exception that for this analysis we kept all observations with simultaneously non-zero transfers received or sent to persons. This data filtering yielded 15,559 observations from the pooled 1992 and 1996 surveys.

\footnotetext{
${ }^{13}$ One of the cases occur in stage II when the price of a non-tradable is cheaper in the destination country and one household member lives in the origin country and transfers money to purchase this good (e.g. house) in the destination country. The other case occurs in stage IV under limited dual citizenship where one spouse remains in the destination country to gain citizenship whilst the other spouse works in the origin country and sends funds to country B.

${ }^{14}$ The model permits the possibility of other agents beyond the spouse who live outside the immediate household to transfer funds. For example, parents of either spouse may live abroad and send monies to their grandchildren resident in the destination country. Thus, one adult child in the destination can send money to his parent abroad whilst the other spouse's parent can send money to the grandchild resident in the destination country. This creates the case of the simultaneous transmission of funds between countries A and B.
} 
Table 2: Descriptive Statistics for Transfers Received, pooled 1992 and 1996 surveys Variable

Population

Canadian

N.Am.\&W.Eu.

S\&E Europ.

Ch.,Asian\&Oc.

Tr. rem. Tr. rec. Net tr. Tr. rem. Tr. rec. Net tr. Tr. rem. Tr. rec. Net tr. Tr. rem. Tr. rec. Net tr.

\begin{tabular}{|c|c|c|c|c|c|c|c|c|c|c|c|c|}
\hline Woman as $\mathrm{HH}$ head & 0.45 & 0.47 & 0.45 & 0.44 & 0.44 & 0.44 & 0.36 & 0.38 & 0.36 & 0.39 & 0.38 & 0.40 \\
\hline Age of $\mathrm{HH}$ head & 47.74 & 46.25 & 47.60 & 54.76 & 53.17 & 54.68 & 53.76 & 52.95 & 53.79 & 45.16 & 44.79 & 45.09 \\
\hline Education & 2.86 & 2.88 & 2.83 & 3.09 & 3.13 & 3.07 & 2.44 & 2.40 & 2.43 & 3.45 & 3.50 & 3.41 \\
\hline HH size & 2.57 & 2.62 & 2.57 & 2.37 & 2.39 & 2.36 & 2.76 & 2.78 & 2.77 & 3.39 & 3.21 & 3.35 \\
\hline HH income after taxes & 39,694 & 39,021 & 38,821 & 40,748 & 40,829 & 40,166 & 39,120 & 38,858 & 38,653 & 43,787 & 43,107 & 42,902 \\
\hline Net change in assets & 2,838 & 2,648 & 2,736 & 3,261 & 3,086 & 3,134 & 1,796 & 2,269 & 1,741 & 2,667 & 2,625 & 2,443 \\
\hline Transfers remitted & 1,454 & & & 2,104 & & & 1,936 & & & 1,602 & & \\
\hline Transfers received & & 675 & & & 574 & & & 534 & & & 639 & \\
\hline Net transfers & & & 850 & & & 1,565 & & & 1,540 & & & 1,158 \\
\hline Observations & 12,406 & 9,949 & 13,365 & 1,045 & 808 & 1,114 & 556 & 347 & 579 & 471 & 265 & 501 \\
\hline
\end{tabular}

Source: Authors' calculations; Family Expenditures Survey 1992 and 1996, Statistics Canada.

Notes: Net transfers are calculated as transfers to persons minus transfers received. Monetary values in 1992 dollars.

Table 2 reports that for all Canadian households, regardless of origin, the average amount of transfers remitted is much greater than the average amount of transfers received. Thus, net transfers are positive. The highest average transfers were reported for North America, West European and South and East European immigrant households. Nonetheless, negative transfers are substantial in all cases with Asian households in particular receiving a substantial amount (CA\$ 639).

\section{Econometric Specification}

It is a basic premise of this paper that the act of private transfers is embedded in the household's utility maximisation framework (eq.1) and is thus a part of the household's allocation process across a general expenditure system. To reflect this, the chosen demand system used in this paper is the Linear Approximate/ Almost Ideal Demand System (LA/AIDS). Thus, for the $\left(i^{\text {th }}\right)$ commodity, the model can be specified as follows:

$$
w_{i}=\alpha_{i}+\sum_{j} \gamma_{i j} \ln p_{j}+\beta_{i} \ln \left(y / p^{*}\right)+\varepsilon_{i}
$$

where $\left(w_{i}=p_{i} \times q_{i} / y\right)$ is the budget share of the $\left(\mathrm{i}^{\text {th }}\right)$ good, $\left(\mathrm{p}_{\mathrm{j}}\right)$ is the price of the $\left(\mathrm{j}^{\mathrm{th}}\right)$ good, (y) is total expenditure, and $\left(p^{*}\right)$ is a Stone price index $\left(\ln p^{*}=\sum w_{i} \ln p_{i}\right)$. To insure that this demand system conforms to the recognised properties of the utility maximisation model outlined in (eq. 1) equation (5.1) must satisfy the adding up, homogeneity and symmetry conditions:

$$
\text { a) adding up: } \quad \sum_{i=1}^{n} \alpha_{i}=1 ; \sum_{i=1}^{n} \beta_{i}=0 ; \sum_{i=1}^{n} \gamma_{i j}=0
$$


b) homogeneity: $\sum_{j=1}^{n} \gamma_{i j}=0$

C) symmetry: $\quad \gamma_{i j}=\gamma_{j i}$

Provided that (5.1.1), (5.1.2), and (5.1.3) hold, equation (5.1) represents a system of demand functions that are homogenous of degree zero in prices and total expenditures and also satisfy the Slutsky symmetry conditions. The LA/AIDS is simple to interpret: in case of constant relative prices and "real” expenditure $\left(y / p^{*}\right)$ the budget shares are constant. This is the natural starting point for the predictions using the model. Changes in relative prices work through the terms $\left(\gamma_{i j}\right)$; each $\left(\gamma_{i j}\right)$ represents 100 times the effect on the $\left(\mathrm{i}^{\text {th }}\right)$ budget share of a 1 percent increase in the $\left(i^{\text {th }}\right)$ price with $\left(y / p^{*}\right)$ held constant. Changes in real expenditure operate through the $\left(\beta_{i}\right)$ coefficients; these add to zero and are positive for luxuries and negative for necessities. Using the estimate $\left(\beta_{i}\right)$ Engel elasticities can be calculated as follows:

$$
e_{i}=1+\frac{\beta_{i}}{w_{i}^{*}}
$$

where $\left(\mathrm{e}_{\mathrm{i}}\right)$ is the Engel elasticity and $\left(w_{i}^{*}\right)$ is the mean share of expenditures on the $\left(\mathrm{i}^{\mathrm{th}}\right)$ good for the entire sample. The Engel elasticity is greater than unity for luxuries, less then unity for necessities, and equal to one for normal goods.

A demographically enhanced demand system can be written as follows:

$$
w_{i}=\alpha_{i}+\sum_{j=1}^{n} \gamma_{i j} \ln p_{j}+\beta_{i} \ln \left(y / p^{*}\right)+\delta_{i k} X_{k}+\varepsilon_{i}
$$

where $\left(X_{k}\right)$ is a the set of demographic control variables drawn from our model that depict the life-cycle stage of the household.

Finally, we have a demand system which is particular interest to us since it allows us to estimate both cohort and assimilation effects:

$$
w_{i}=\alpha_{i}+\sum_{j=1}^{n} \gamma_{i j} \ln p_{j}+\beta_{i} \ln \left(y / p^{*}\right)+\delta_{i k} X_{k}+\sum_{s}\left(\phi_{i s}+\theta_{i s} D\right) \times R_{s}+\varepsilon_{i}
$$

where $\left(R_{s}\right)$ is a dummy variable that is equal to one if the household belongs to immigrant group (s) and zero otherwise. (D) denotes the duration of the foreign-born household residence (vintage of immigrant). This extended model is designed to match the description of 
the behaviour of immigrants in the sociology literature. ${ }^{15}$ In that literature the immigrants are assumed to arrive with a set of cultural values and tastes which are different from those of the natives; this is reflected by possible non-zero values for $\left(\phi_{\text {is }}\right)$. Over time, via assimilation, the behaviour of immigrants may become more similar to that of the natives. In our model this would be the case when the sign of $\left(\theta_{i s}\right)$ is opposite to the sign of $\left(\phi_{i s}\right)$. In this case, after $\phi_{i s} / \theta_{i s}$ years in the host country, the immigration and cultural effects would reach zero. Thus, the set of parameters $\left(\phi_{i s}\right)$ can be interpreted first as a general immigration entry effect. If $\left(\phi_{i s}\right)$ differs significantly across immigrant groups, we interpret this as evidence for country specific cultural effects as well. ( $\left.\theta_{i s}\right)$ can be interpreted as the assimilation effect on transfers over time, but if $\left(\theta_{i s}\right)$ differs significantly across immigrant groups, we shall have found evidence of a cultural effect on the speed of assimilation. ${ }^{16}$

\section{Empirical Results}

LA/AIDS is a system of seemingly unrelated equations with identical repressors and crossequation restrictions, e.g. $\gamma_{i j}=\gamma_{j i}$. For its estimation we thus use Zellner's Seemingly Unrelated Regression (SUR). For the dependent variable the following must hold: $\sum_{i=1}^{n} w_{i}=1$. This restriction implies further restrictions on the right hand side, in particular $\sum_{i=1}^{n} \varepsilon_{i}=0$. The residuals are linear dependent and their covariance matrix is singular. ${ }^{17}$ Green (2003) shows that the solution to the singularity problem is to arbitrary drop one of the equations and estimate the remainder. The residuals covariance matrix of the system with $(n-1)$ equations is non-singular. The coefficients of the $\left(\mathrm{n}^{\text {th }}\right)$ equation result from the "adding-up" restriction. Furthermore, in the SUR-model, when all equations have the same regressors, the efficient estimator is single-equation ordinary least squares; GLS is the same as OLS. Thus, we use in this analysis SUR and OLS alternatively: SUR in most case, in particular when we impose cross-equation restrictions and OLS for single equation estimations.

Furthermore, structural breaks may occur in the sample since the data set is pooled. To account for this we estimated the system of equations with variables which captured the

\footnotetext{
${ }^{15}$ See Thomas (1992).

${ }^{16}$ See Carroll et al. (1994) for this interpretation.

17 See Hansen (1993).
} 
interaction for the years 1992 and 1996 and the income variable. However, the difference between the coefficients of these interaction variables is quite small, implying that the income elasticity is about the same for 1992 and 1996. Thus, it is reasonable to run the analysis with the pooled sample. ${ }^{18}$

\section{Homogeneity and symmetry}

One of the tasks of this empirical analysis is to test if the restrictions implied by utility theory hold for our demand equations. The homogeneity restriction is first tested by running separate OLS regressions for each commodity group in our study, with and without the restriction imposed. Then, we tested for homogeneity, symmetry and both homogeneity and symmetry by running SUR for the whole system, with and without the restrictions imposed. A likelihood ratio test is used to test the restrictions in the uncontrolled for demographics LA/AIDS model (eq. 5.1). ${ }^{19}$

Table 3: Homogeneity and Symmetry

\begin{tabular}{lcccccccc} 
Commodity Group & \multicolumn{9}{c}{ Population } \\
& \multicolumn{2}{c}{ Canadian } & \multicolumn{1}{c}{ N.Am.\&W.Eu. } & \multicolumn{2}{c}{ S\&E Eu. } & \multicolumn{2}{c}{ Ch.,As.\&Oc. } \\
\cline { 2 - 9 } & chi $^{2}(\mathbf{1})$ & p-value & chi $^{2} \mathbf{( 1 )}$ & p-value & chi $^{2}(\mathbf{1})$ & p-value & chi $^{2}(\mathbf{1})$ & p-value \\
\cline { 2 - 9 } Food & 0.04 & $\mathbf{0 . 8 4 4}$ & 0.01 & $\mathbf{0 . 9 3 3}$ & 0.00 & $\mathbf{0 . 9 7 3}$ & 0.64 & $\mathbf{0 . 4 2 5}$ \\
Shelter & 32.13 & 0.000 & 7.16 & 0.008 & 1.16 & $\mathbf{0 . 2 8 1}$ & 0.14 & $\mathbf{0 . 7 1 3}$ \\
HH op\&fur & 0.88 & $\mathbf{0 . 3 4 8}$ & 0.06 & $\mathbf{0 . 8 0 0}$ & 3.71 & 0.054 & 2.40 & $\mathbf{0 . 1 2 1}$ \\
Clothing & 1.50 & $\mathbf{0 . 2 2 1}$ & 6.71 & 0.010 & 10.53 & 0.001 & 0.74 & $\mathbf{0 . 3 9 0}$ \\
Transportation & 0.54 & $\mathbf{0 . 4 6 1}$ & 1.20 & $\mathbf{0 . 2 7 4}$ & 0.64 & $\mathbf{0 . 4 2 5}$ & 0.26 & $\mathbf{0 . 6 0 8}$ \\
Heath\&Pers.Care & 22.04 & 0.000 & 0.80 & $\mathbf{0 . 3 7 0}$ & 0.69 & $\mathbf{0 . 4 0 8}$ & 4.72 & 0.030 \\
Recreation & 0.24 & $\mathbf{0 . 6 2 5}$ & 0.00 & $\mathbf{0 . 9 9 3}$ & 0.09 & $\mathbf{0 . 7 6 8}$ & 0.19 & $\mathbf{0 . 6 6 6}$ \\
Tabacco\&Alcohol & 34.22 & 0.000 & 0.54 & $\mathbf{0 . 4 6 1}$ & 0.40 & $\mathbf{0 . 5 2 7}$ & 3.85 & 0.050 \\
Transf. to pers. & 0.00 & $\mathbf{0 . 9 6 6}$ & 0.07 & $\mathbf{0 . 7 9 7}$ & 0.14 & $\mathbf{0 . 7 0 5}$ & 2.51 & $\mathbf{0 . 1 1 3}$ \\
Transf. to char. & 15.34 & 0.000 & 0.01 & $\mathbf{0 . 9 2 3}$ & 4.53 & 0.033 & 0.58 & $\mathbf{0 . 4 4 6}$ \\
\hline System & & & & & & & & \\
$\quad$ Homogeneity & 100.65 & 0.000 & 14.93 & 0.093 & 20.25 & 0.016 & 14.26 & $\mathbf{0 . 1 1 3}$ \\
$\quad$ Symmetry & 7676.51 & 0.000 & 260.85 & 0.000 & 110.91 & 0.000 & 102.72 & 0.000 \\
Homog.\&Symmetry & 7829.59 & 0.000 & 267.43 & 0.000 & 131.07 & 0.000 & 118.42 & 0.000 \\
\hline
\end{tabular}

Note: Significant results in bold type.

The test results for homogeneity and symmetry are presented in Table 3. Since we assumed different expenditure patterns for the four population groups in our study, we ran the tests for each group separately. In fact, different results are generated by the restriction tests. By running separate OLS regressions, the hypothesis of homogeneity cannot be rejected in six

\footnotetext{
${ }^{18}$ The system exhibits heteroskedasticity. Tests like White and Breusch-Pagan/ Cook-Weisberg reject the null of homoskedasticity. The source of heteroskedasticity is uncertain moreover, weighting the OLS regressions by the deflated logarithm of expenditure does not eliminate heteroskedasticity.
} 
out of ten equations in the system for the Canadian-born population, seven out of ten equations for the South and East European immigrant population, and eight out of ten equations for the North American and West European and Asian immigrant population. When running the entire system, the homogeneity restriction cannot be rejected in the case of the Asian immigrant case. Finally, the symmetry restriction is rejected by the chi-squared statistics for all population groups.

\section{Income elasticities}

Given our earlier reported stylised facts, we will estimate Engel elasticities for Canadianborn, and foreign-born residents across income groups under an LA/AIDS system. ${ }^{20}$ We will estimate uncontrolled as well as a controlled model to calculate Engel elasticities.

The model includes controls for gender, age, household size, education, house ownership and savings variables to capture our models main socio-economic life-cycle arguments which may influence the household's decision to transfer money outside the household. If our model is correct and demographic arguments condition remittances then significant differences should arise between the controlled and uncontrolled elasticity measures.

Table 4 reports the estimated expenditure elasticities for the pooled 1992 and 1996 surveys for transfers to persons in a controlled and uncontrolled setting with and without imposing restrictions for homogeneity and symmetry. We differentiate further by foreignbirth status and income group to capture any effects owing to the immigrant origins or their position in Canada's income distribution. Given these categories the range of calculated values for the expenditure elasticities indicate that transfers to persons range from a luxury item to a necessity across the sampled households. ${ }^{21}$

The results indicate significant cultural differences in the remittance activity and imply different economic relationship with their relatives. The uncontrolled elasticity estimates are above unity for the Canadian-born and North American and West European immigrant households and close to unity for South and East European and Asian immigrant households. North Americans and West Europeans seem to treat transfers to relatives as being

\footnotetext{
${ }^{19}$ For the prices used for estimating the system see Appendix A.

${ }^{20}$ Test results for weak separability of expenditure groups suggest that Asian households treat transfers to persons and transfers to charity as weakly separable from the other expenditures. Thus, the LA/AIDS estimates for the Asian group they include instead of total expenditures only transfers to persons and transfers to charity.

${ }^{21}$ For expenditure elasticities for the entire system see Appendix B. Canadian elasticity estimates as reported by Didukh (2001, 2002) and Geiger (2002) over a wide variety of commodities are in the range reported here with the exception of the Chinese values.
} 
a luxury item, while South and East European and Asian immigrants treats transfers more like a normal good. Once controls for gender, age, education, number of persons in the household, house ownership and saving activity are added then the elasticity values regardless of foreignbirth status (except Asian) greatly exceed unity. This indicates that in general in this controlled environment remittances are treated as luxury goods. The exception is the Asian household which treats remittances as normal good regardless of the imposition of controls. Expenditure elasticities with the homogeneity and symmetry restrictions mimic those of the unrestricted estimation.

Table 4: Expenditure Elasticities for Transfers to Persons Calculated from LA/AIDS, 1992/1996

\begin{tabular}{|c|c|c|c|c|c|c|c|}
\hline & \multirow{3}{*}{$\begin{array}{l}\text { Population } \\
\text { Group }\end{array}$} & \multicolumn{3}{|c|}{ Uncontrolled } & \multicolumn{3}{|c|}{ Controlled } \\
\hline & & \multicolumn{3}{|c|}{ Income Group } & \multicolumn{3}{|c|}{ Income Group } \\
\hline & & all & top $Y / 2$ & bottom Y/2 & all & top $Y / 2$ & bottom $Y / 2$ \\
\hline \multirow{4}{*}{ Unrestricted } & Canadian & 1.07 & 1.27 & 1.19 & 1.83 & 1.73 & 1.82 \\
\hline & N.Am.\&W.Eu. & 1.29 & 1.43 & 1.67 & 2.21 & 2.12 & 2.16 \\
\hline & S\&E European & 1.01 & 1.11 & 1.09 & 2.04 & 1.58 & 2.24 \\
\hline & Ch.,As.\&Oc. & 1.09 & 1.12 & 1.09 & 1.10 & 1.12 & 1.10 \\
\hline \multirow{4}{*}{$\begin{array}{l}\text { Restricted for } \\
\text { Homogeneity } \\
\text { and Symmetry }\end{array}$} & Canadian & 1.09 & 1.25 & 1.20 & 1.82 & 1.69 & 1.80 \\
\hline & N.Am.\&W.Eu. & 1.29 & 1.43 & 1.66 & 2.21 & 2.10 & 2.15 \\
\hline & S\&E European & 0.98 & 1.06 & 1.08 & 2.00 & 1.54 & 2.21 \\
\hline & Ch.,As.\&Oc. & 1.09 & 1.12 & 1.10 & 1.10 & 1.12 & 1.10 \\
\hline
\end{tabular}

Notes: Elasticity is computed through the formula $e_{i}=1+\left(\beta_{i} / w_{i}^{*}\right)$, where $\left(w_{i}^{*}\right)$ is the actual mean expenditure share and $\left(\beta_{i}\right)$ is the estimated household income coefficient.

Table 5 focuses on charitable donations of households by their income class. In an uncontrolled setting, across all population and income groups, the households treated charitable donations as a necessity. The single exception are North American and West European in the bottom income half, whose expenditure elasticity slightly exceeded unity. These results are repeated in a controlled setting (South and East European immigrants are an exception).

Some tentative conclusions are in order. Since most foreign-born Canadian households treat transfers to persons outside the household as a luxury good we conclude that we have found evidence of an altruistic behaviour. Asian households are the exception since their remitting behaviour supports the implicit family loan agreement theory, given that remittances are seen as a necessity and thus more stable when related to income changes. On 
the other hand, most households seem to treat transfers to charity as gifts, since these transfers are small and fall as a share of total expenditures as income rises. ${ }^{22}$

Table 5: Expenditure Elasticities for Transfers to Charity Calculated from LA/AIDS, 1992/1996

\begin{tabular}{lccccccc} 
& $\begin{array}{c}\text { Population } \\
\text { Group }\end{array}$ & \multicolumn{3}{c}{ Uncontrolled } & \multicolumn{3}{c}{ Controlled } \\
\cline { 3 - 8 } & & all & $\begin{array}{c}\text { Income Group } \\
\text { top Y/2 }\end{array}$ & bottom Y/2 & all & $\begin{array}{c}\text { Income Group } \\
\text { top Y/2 }\end{array}$ & bottom Y/2 \\
\hline \multirow{3}{*}{ Unrestricted } & Canadian & 0.60 & 0.48 & 0.47 & 0.96 & 0.70 & 0.94 \\
& N.Am.\&W.Eu. & 0.78 & 0.65 & 1.03 & 1.19 & 0.78 & 1.26 \\
& S\&E European & 0.54 & 0.97 & 0.32 & 1.25 & 1.09 & 1.18 \\
& Ch.,As.\&Oc. & 0.79 & 0.76 & 0.78 & 0.77 & 0.74 & 0.77 \\
\hline \multirow{2}{*}{ Restricted for } & Canadian & 0.67 & 0.56 & 0.50 & 0.97 & 0.72 & 0.93 \\
Homogeneity & N.Am.\&W.Eu. & 0.79 & 0.66 & 1.02 & 1.18 & 0.77 & 1.24 \\
and Symmetry & S\&E European & 0.56 & 0.97 & 0.40 & 1.28 & 1.11 & 1.23 \\
& Ch.,As.\&Oc. & 0.79 & 0.75 & 0.77 & 0.77 & 0.74 & 0.76 \\
\hline
\end{tabular}

Notes: Elasticity is computed through the formula $e_{i}=1+\left(\beta_{i} / w_{i}^{*}\right)$, where $\left(w_{i}^{*}\right)$ is the actual mean expenditure share and $\left(\beta_{i}\right)$ is the estimated household income coefficient.

\section{Demographic Controls}

We now turn to the effects of household demographic characteristics on remittance behaviour. Since we earlier argued that remittances are embedded in the household's life cycle experiences we will depict the household's remittance experience with a series of simulations. These simulations are depicted in Figures 2 and 3 and are constructed from the reported estimates for transfers to persons and transfers to charity in Appendix C. In short, for each representative household we place the mean values for all the model's variables (except age) and cross multiply by the relevant coefficients. This produces the household's estimated budget transfer share by age for total transfers and its constituent parts. ${ }^{23}$

Figure 2 reveals several important features of the remittance experience across age and various population groups. First, there exists a substantial difference in remittances to persons as a share of household expenditures between Asian immigrants and all other groups. The share of transfers to persons as a percentage of total expenditures rises with age for all other groups from about 2.5 to 3.0 percent at age 25 to about 6 percent at age 70 . Conversely, the pattern of remittances to persons for Asian immigrant households remain relatively flat over their whole life cycle at about 4 percent of total expenditures.

\footnotetext{
22 The single exception are South and East European immigrants, who tend to be more altruistic in their relation to social/religious groups.

${ }^{23}$ When simulating the absolute amount of transfers, we used estimates derived from the controlled LA/AIDS model with the dependent variable and the independent variables of the basic model multiplied by total expenditures.
} 
If we now turn to the simulated absolute values transferred we generate patterns which conform to our earlier reported stylised facts. In short, North American and West European immigrant households remit the greatest absolute amounts and Canadian-born households the least, with an almost constant difference (about CA\$ 400) between the two groups over their households' lifetimes.

Figure 2: HH Transfers to Persons by Population Group during Life Cycle (share and absolute)
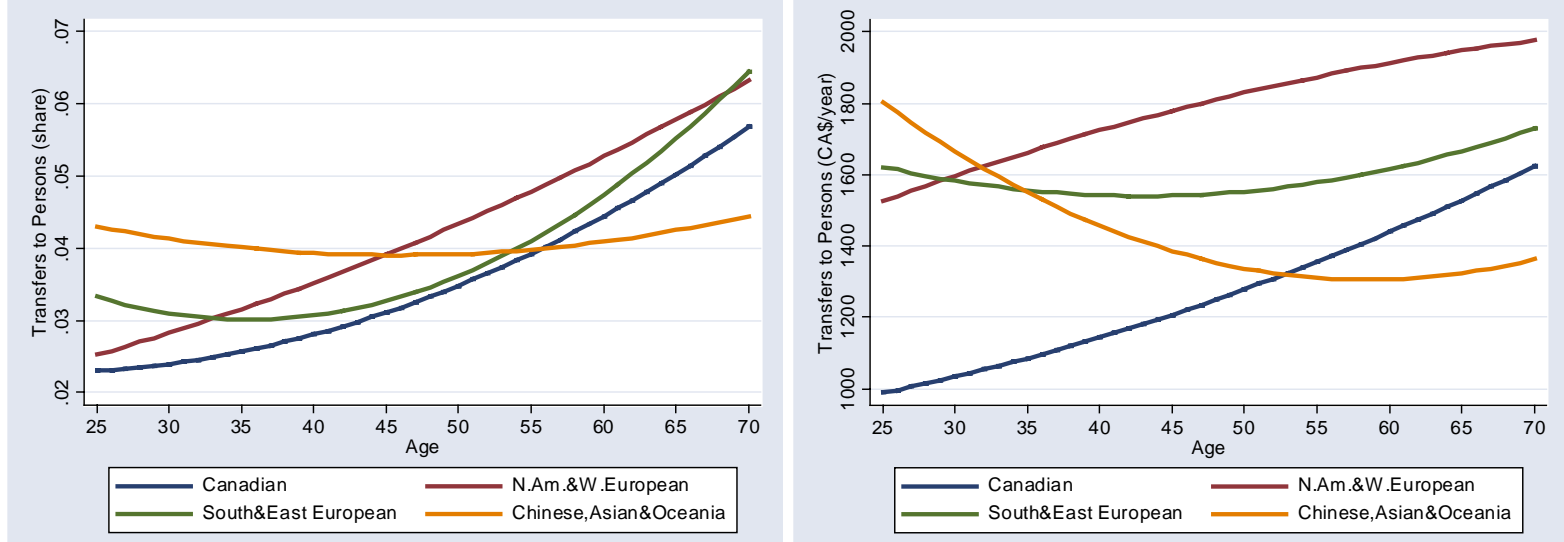

Source: Author's calculations; Family Expenditures Survey (FAMEX) 1992 and 1996, Statistics Canada.

We can further recognise important entry and assimilation effects in the households' remittance patterns. For the Canadian-born and North American and West European households the remittance patterns in absolute terms are almost linear and increasing, while for South and East European immigrant households it is convex with a minimum of about 1,500 CA \$/year at age 45 and for Asian immigrant households it is also convex with a minimum of about 1,300 CA \$/year at age 60 .

Figure 3: HH Transfers to Charity by Population Group during Life Cycle (share and absolute)
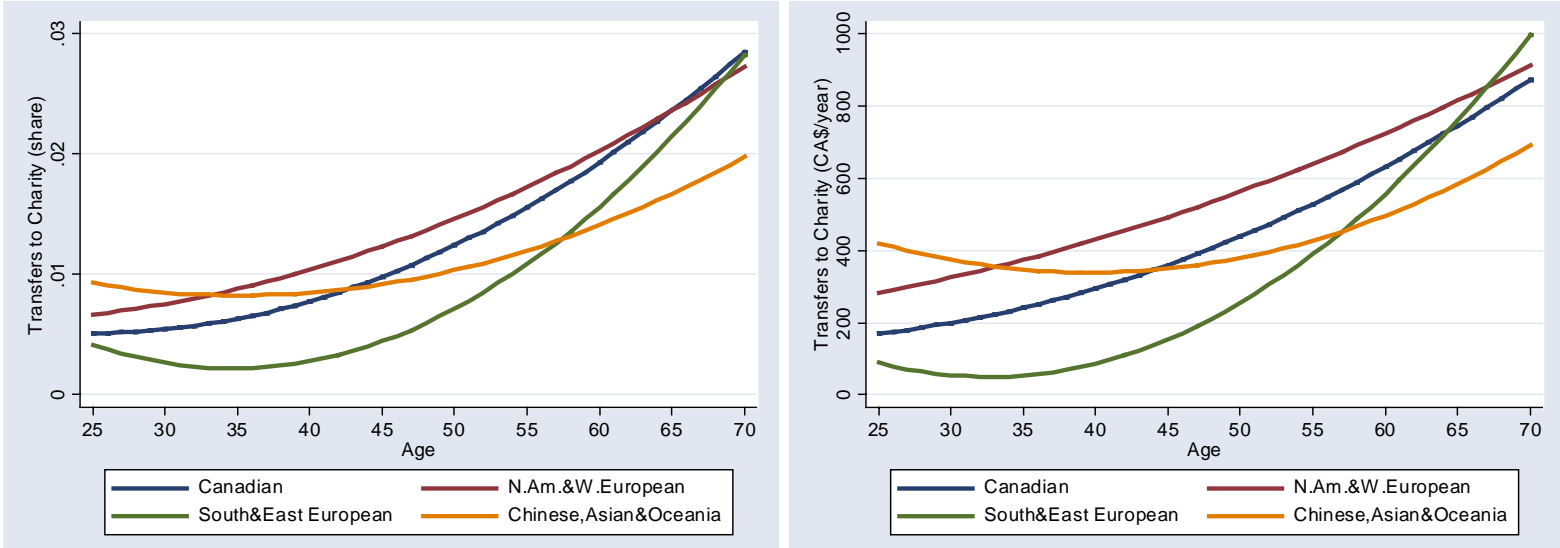

Source: Author's calculations; Family Expenditures Survey (FAMEX) 1992 and 1996, Statistics Canada.

Figure 3 depicts the simulated charitable transfers by various households. In general all household groups (except Asian) increase there minuscule charitable donations from a half of 
one percent at age 25 to around 3 percent by age 70. Additionally, charitable donations, both as a share and in absolute values, tend to converge over the life cycle across various population groups with the exception of the charitable donations of the Asian immigrant households.

\section{Entry and Assimilation Effects}

Table 6 reports the results of estimating the augmented share equation with the entry and assimilation effects in $1992 .{ }^{24}$ The reported standard errors are corrected for heteroskedasticity. ${ }^{25}$ We found the $\left(\phi_{\text {is }}\right)$ coefficient as significant only for transfers to charity and in the case of North American and West European and Asian household, indicating a small but significant immigration effect. In addition, the result of the F-test shows that ( $\left.\phi_{i s}\right)$ is significantly similar (at a 1\% level) across immigrant groups, which suggests that there is no evidence for cultural effects on charitable donations at time of entry. The $\left(\theta_{i s}\right)$ coefficient is very small across all immigrant groups regardless of type of transfer, but significant only in the case of charitable donations and for North American and West Europeans. Furthermore, the $\left(\theta_{i s}\right)$ coefficient differs significantly across groups which supports the existence of cultural effects on the speed of assimilation.

Table 6: Entry and Assimilation Effects, 1992

Transfers to Persons

Transfers to Charity

\begin{tabular}{|c|c|c|c|c|c|c|c|c|}
\hline \multirow[b]{2}{*}{$\begin{array}{c}\text { Population } \\
\text { Group }\end{array}$} & \multicolumn{2}{|c|}{ Entry } & \multicolumn{2}{|c|}{ Assimilation } & \multicolumn{2}{|c|}{ Entry } & \multicolumn{2}{|c|}{ Assimilation } \\
\hline & Coefficient & $\begin{array}{l}\text { F-test } \\
(p-v a l .)\end{array}$ & Coefficient & $\begin{array}{l}\text { F-test } \\
\text { (p-val.) }\end{array}$ & Coefficient & $\begin{array}{c}\text { F-test } \\
\text { (p-val.) }\end{array}$ & Coefficient & $\begin{array}{c}\text { F-test } \\
\text { (p-val.) }\end{array}$ \\
\hline N.Am\&W.Eu. & $\begin{array}{c}0.0070 \\
{[0.0080]}\end{array}$ & & $\begin{array}{l}-0.0002 \\
{[0.0003]}\end{array}$ & & $\begin{array}{c}-0.0113 \\
{[0.0041]^{\star \star \star}}\end{array}$ & & $\begin{array}{c}0.0004 \\
{[0.0002]^{\star \star}}\end{array}$ & \\
\hline S\&E European & $\begin{array}{l}-0.0076 \\
{[0.0097]}\end{array}$ & 0.2655 & $\begin{array}{c}0.0006 \\
{[0.0004]}\end{array}$ & 0.4836 & $\begin{array}{l}-0.0033 \\
{[0.0024]}\end{array}$ & 0.0052 & $\begin{array}{c}-0.000001 \\
{[0.0001]}\end{array}$ & 0.1138 \\
\hline Ch.,Asian\&Oc. & $\begin{array}{c}0.0183 \\
{[0.0115]}\end{array}$ & & $\begin{array}{l}-0.0003 \\
{[0.0008]}\end{array}$ & & $\begin{array}{c}-0.0057 \\
{[0.0031]^{\star}}\end{array}$ & & $\begin{array}{c}0.0002 \\
{[0.0002]}\end{array}$ & \\
\hline
\end{tabular}

In sum, we found on the one hand no significant entry and assimilation effects with respect to transfers to persons. On the other hand, charitable donations by the foreign-born are slightly lower at entry and they gradually rise and assimilate to Canadian-born donation levels after 26 or more years.

\footnotetext{
${ }^{24}$ The 1996 survey data do not contain a question on the number of years in Canada so only the 1992 data was employed.
} 


\section{Transfers Received}

We now test to see if the transfer model can explain the reported negative transfers. We argued that the relative prices for non-tradables between Canada and the home country and the presence of dependents (spouse and or children) in Canada (country A) and the earning power of the spouse resident in Canada should condition the size of the transfers received. Table 7 reports the findings for this model when we control for these variables.

Contrary to expectations a rise in household income is positively related to the amount of transfers received across all groups. We found gender to significantly influence the amount of transfers received, with households with females as head receiving more transfers. The presence of family members in the household (significant for Canadian-born and North American and West European households) increases the amount of transfers received as well. Finally, as in the case of remitted transfers, received transfers have a U-shape pattern with respect to age.

At this point we would like to contrast the negative transfer behaviour with factors which in influence the joint movement of remittances to and from households. Table 8 reports the variables which condition the size of the net transfers across the Canadian resident households in the pooled 1992 and 1996 sample.

Table 7: Regression Coefficients (OLS) Predicting Log of Transfers Received, 1992/1996 Canadian N.Am\&W.Eu. S\&E Eu. Ch.,As.\&Oc.

\begin{tabular}{|c|c|c|c|c|}
\hline Log income & $\begin{array}{c}0.510 \\
{[0.025]^{\star \star \star}}\end{array}$ & $\begin{array}{c}0.463 \\
{[0.090]^{\star \star \star}}\end{array}$ & $\begin{array}{c}0.724 \\
{[0.157]^{\star \star \star}}\end{array}$ & $\begin{array}{c}0.600 \\
{[0.202]^{\star \star \star}}\end{array}$ \\
\hline Female & $\begin{array}{c}0.137 \\
{[0.021]^{\star \star \star}}\end{array}$ & $\begin{array}{c}0.300 \\
{[0.076]^{\star \star \star}}\end{array}$ & $\begin{array}{c}0.232 \\
{[0.124]^{\star}}\end{array}$ & $\begin{array}{c}0.169 \\
{[0.155]}\end{array}$ \\
\hline Age & $\begin{array}{c}-0.056 \\
{[0.005]^{\star \star \star}}\end{array}$ & $\begin{array}{c}-0.063 \\
{[0.020]^{\star \star \star}}\end{array}$ & $\begin{array}{l}-0.020 \\
{[0.040]}\end{array}$ & $\begin{array}{c}-0.092 \\
{[0.042]^{\star *}}\end{array}$ \\
\hline Age - squared $(x 1,000)$ & $\begin{array}{c}0.473 \\
{[0.054]^{\star \star \star}}\end{array}$ & $\begin{array}{c}0.542 \\
{[0.192]^{\star \star \star}}\end{array}$ & $\begin{array}{c}0.158 \\
{[0.378]}\end{array}$ & $\begin{array}{c}0.906 \\
{[0.433]^{\star \star}}\end{array}$ \\
\hline Education & $\begin{array}{c}0.042 \\
{[0.009]^{\star \star \star}}\end{array}$ & $\begin{array}{c}0.078 \\
{[0.031]^{\star \star}}\end{array}$ & $\begin{array}{c}0.059 \\
{[0.046]}\end{array}$ & $\begin{array}{c}0.054 \\
{[0.057]}\end{array}$ \\
\hline No. Of Persons a Member & $\begin{array}{c}0.038 \\
{[0.010]^{\star \star \star}}\end{array}$ & $\begin{array}{c}0.120 \\
{[0.039]^{\star \star \star}}\end{array}$ & $\begin{array}{l}-0.041 \\
{[0.072]}\end{array}$ & $\begin{array}{c}0.011 \\
{[0.067]}\end{array}$ \\
\hline Net change in A\&L $(x 100,000)$ & $\begin{array}{c}0.327 \\
{[0.078]^{\star \star \star}}\end{array}$ & $\begin{array}{c}0.214 \\
{[0.216]}\end{array}$ & $\begin{array}{c}0.825 \\
{[0.428]^{*}}\end{array}$ & $\begin{array}{c}0.432 \\
{[0.460]}\end{array}$ \\
\hline Constant & $\begin{array}{c}4.117 \\
{[0.163]^{\star \star \star}}\end{array}$ & $\begin{array}{c}4.071 \\
{[0.639]^{\star \star \star}} \\
\end{array}$ & $\begin{array}{r}1.869 \\
{[1.119]^{\star}}\end{array}$ & $\begin{array}{c}4.013 \\
{[1.346]^{\star \star \star}}\end{array}$ \\
\hline $\begin{array}{l}\text { Observations } \\
\text { R-squared }\end{array}$ & $\begin{array}{l}9949 \\
0.12\end{array}$ & $\begin{array}{l}808 \\
0.15\end{array}$ & $\begin{array}{l}347 \\
0.13\end{array}$ & $\begin{array}{l}265 \\
0.07\end{array}$ \\
\hline Robust standard errors in brackets & 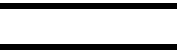 & & & \\
\hline
\end{tabular}

\footnotetext{
${ }^{25}$ The results without adjusting for heteroskedasticity are similar.
} 
Table 8: Regression Coefficients (OLS) Predicting Log of Net Transfers, 1992/1996

\begin{tabular}{|c|c|c|c|c|}
\hline & Canadian & N.Am\&W.Eu. & S\&E Eu. & Ch.,As.\&Oc. \\
\hline \multirow[t]{2}{*}{ Log income } & 0.033 & 0.274 & 0.111 & 0.097 \\
\hline & {$[0.003]^{\star \star \star}$} & {$[0.037]^{\star \star \star}$} & {$[0.057]^{\star}$} & {$[0.021]^{\star \star \star}$} \\
\hline \multirow[t]{2}{*}{ Female } & -0.004 & 0.017 & -0.019 & -0.002 \\
\hline & {$[0.002]$} & {$[0.020]$} & [0.044] & [0.033] \\
\hline \multirow[t]{2}{*}{ Age $(x 1,000)$} & 0.013 & 0.451 & 0.603 & 0.490 \\
\hline & {$[0.004]$} & {$[0.046]$} & {$[0.097]$} & {$[0.083]$} \\
\hline \multirow[t]{2}{*}{ Age - squared $(x 1,000)$} & 0.005 & -0.008 & -0.005 & -0.027 \\
\hline & {$[0.004]$} & {$[0.046]$} & {$[0.077]$} & {$[0.072]$} \\
\hline \multirow[t]{2}{*}{ Education } & -0.001 & -0.030 & -0.010 & 0.015 \\
\hline & [0.001] & {$[0.011]^{\star \star \star}$} & {$[0.011]$} & {$[0.023]$} \\
\hline \multirow[t]{2}{*}{ No. Of Persons a Member } & -0.008 & -0.085 & 0.002 & -0.041 \\
\hline & {$[0.001]^{\star \star \star}$} & {$[0.019]^{\star \star \star}$} & {$[0.039]$} & {$[0.024]^{\star}$} \\
\hline \multirow[t]{2}{*}{ Net change in A\&L $(x 100,000)$} & -0.048 & 0.076 & -0.192 & 0.202 \\
\hline & {$[0.017]^{\star \star \star}$} & {$[0.080]$} & [0.249] & {$[0.190]$} \\
\hline \multirow[t]{2}{*}{ Constant } & 10.795 & 7.642 & 8.778 & 9.075 \\
\hline & {$[0.021]^{\star \star \star}$} & {$[0.168]^{\star \star \star}$} & {$[0.200]^{\star \star \star}$} & {$[0.315]^{\star \star \star}$} \\
\hline Observations & 13365 & 1114 & 579 & 501 \\
\hline R-squared & 0.03 & 0.12 & 0.04 & 0.02 \\
\hline
\end{tabular}

Robust standard errors in brackets

* significant at $10 \%$; ** significant at $5 \%$; *** significant at $1 \%$

Notes: Net transfers equal to transfers to persons minus transfers received.

The dependent variable in this case is the difference in the flows of transfers in and out of the household for only those households which had at least a transfer flow in one direction in 1992 and 1996. Income positively affects the log of net transfers as the model would predict. In addition, the presence of family members in the household decreases the net transfers as gross flows from outside to the household increase. The strongest regional results appear for foreign-born immigrants from North America and Western Europe.

\section{Conclusions}

This study, demonstrated the effect of Canada's immigration policy which encourages permanent immigration on remittances since only modest levels of transfers, amounting on average less than 5 percent of overall household expenditures occurs in this context. In addition, these transfers were highly concentrated with the highest 30 percent of earners remitting 80 percent of all remittances. In fact about nine percent of the households did not made any transfer to persons outside the household or charity. Finally, only 25 percent of foreign-born transfers were in the form of charitable donations, while the other 75 percent where in the form of money transfers to persons.

We offered an utility maximising household model to explain the multiple transfer options that appeared in the Canadian context. These options included zero transfers, net positive transfers and negative transfers, i.e. when Canadian foreign-born households received 
foreign funds. The model argued that these alternatives were a by product of Canadian immigration policy and the consequence of the presence or absence of a spouse and/or dependents.

Estimating Engel elasticities with an LA/AIDS model in both a naive formulation and with extended demographic controls confirmed in general that with the important exception of Asian sourced immigrants monetary transfers outside the household were considered a luxury good. However, beyond this generalisation an array of heterogeneous outcomes appeared. First, Asian immigrants appear to have closer ties to relatives and friends, since remittances appear as a normal good. This may imply an implicit loan agreement may exist with the extended family, since they transfer a relative constant share of their income over their lifetime. On the other hand, an altruistic may motivate all other foreign-born households since their share of remittances rose with greater total household expenditures. Moreover, charitable donations are treated as gifts by most foreign-born households, since they are small and falling as a share of total expenditures when income rises. The only exception being South and East European immigrants, which appeared to be more altruistically inclined toward their religious groups.

We found evidence as well that the transfer activity of all Canadian households is sensitive to demographic factors. The strongest demographic control were age which produced lifetime U-shaped transfer patterns and family size which negatively effected the share of remittances to persons. In the case of charity donations, house ownership was positively related to the share of charitable donations. This implies that wealthier people are much more attached to their social/religious groups.

An extended version of the model to capture acculturation effects revealed no significant entry and assimilation effects with respect to foreign-born transfers to persons. However, there is a small but significant immigration effect which initially dampened charitable donations. This entry effect differs significantly across immigrants groups and thus supports the existence of cultural effects upon entry as well. Furthermore, we found evidence for a small assimilation effect for charitable donations as foreign-born charitable transfer behaviour converged to Canadian-born behaviour after 26 to 28 years.

Our model uniquely predicted negative transfers and confirmed that female headed households receive more transfers than males. This may be interpreted by our model as a incentive for foreign-born females to remain in Canada.

In sum, Canada's long standing immigration policy which produced large scale permanent residents produced modest levels of transfers. 


\section{References}

Adams, R.H. (2004), "Remittances, Household Expenditure and Investment in Guatemala”, World Bank, Development Research Group, MSN MC3-303.

Adams, R.H. (1998), “Remittances, Investment and Rural Asset Accumulation in Pakistan”, Economic Development and Cultural Change 47: 155-173.

Aescobar, A. (2004), "Migration and the Diaspora”, Proceedings of Migration and Development: Working with the Diaspora, ILO, Geneva.

Ahlburg, D. and R. Brown (1998), "Migrants' Intentions to Return Home and Capital Transfers: A Study of Tongans and Samoans in Australia”, Journal of Development Studies, 35 (2): 125-51.

Bauer, T. and M. Sinning (2005), "The Savings Behaviour of Temporary and Permanent Migrants in Germany, RWI, Essen.

Brown, R.P.C. (1994), "Migrants' Remittances, Savings and Investment in the South Pacific”, International Labour Review 133(3): 347-67.

Canada, CIC (2002), Facts and Figures 2002: Statistical Overview of the Temporary Resident and Refugee Claimant Population. http://www.cic.gc.ca/english/pub/facts2002-temp/factstemp-3.html

Carroll, C., Rhee, B.K. and C. Rhee (1994), “Are there Cultural Effects on Saving? Some cross-sectional Evidence”, The Quarterly Journal of Economics 35(3) (August): 685-699.

Cox, D. (1987) “Motives for Private Income Transfers”, Journal of Political Economy 95(3): 508-546.

Cox, D. and M.R. Rank (1992), "Inter-vivo Transfers and Intergenerational Exchange”, The Review of Economics and Statistics 72(4): 305-14.

Deaton, A. and J. Muelbauer (1980), “An Almost Ideal Demand System”, American Economic Review 70(3): 312-324.

DeVoretz, D. and S. Pivnenko, (2004 forthcoming) “The Economics of Canadian Citizenship` Willi Brandt Working Papers, IMER Malmo University, Malmo Sweden.

Didukh, G. (2002), "Immigrants and the Demand for Housing”, Working paper \#02-01: RIIM, Vancouver.

Duraisamy, P. and S. Narashimhan. (2000), "Migration, Remittances and Family Ties in Urban Informal Sector”, Indian Journal of Labour Economics 43 (1): 111-19.

Lucas, R. and O. Stark (1985), “Motivations to Remit: Evidence from Botswana”, Political Economy 93(5): 901-918. 
Pendakur, K. (2001), “Consumtion Poverty in Canada, 1969 to 1998”, Canadian Public Policy XXVII(2): 125-149.

Semyonov, M. and A. Gorodzeisky (2005), "Labor Migration, Remittances and Household Income: A comparison between Filipino and Filipina Overseas Workers”, International Migration Review 39(1): 45-68.

Shamsuddin, A. and D. J. DeVoretz, (1998), "Wealth Accumulation of Canadian and ForeignBorn Households in Canada”, Review of Income and Wealth 44(4): 515-33.

Statistics Canada (2003), “Ethnic Diversity Survey” Catalogue 89-593-XIE http://www.statcan.ca/english/freepub/89-593-XIE/free.htm

Stark, O. (1991), "Migration, Remittances and the Family”, in The Migration of Labor, ed. Oded Stark. Cambridge, Oxford: Basil Blackwell.

Stark, O. (1995), “Altruism and Beyond: An Economic Analysis of Transfers and Exchanges within Families and Groups”, Oscar Morgenstern Memorial Lectures. Cambridge; New York; and Melbourne: Cambridge University Press: pp. 142

Straubhaar, T. and F. Vadean (2005), "International Migrant Remittances and their Role in Development”, in OECD (ed.): “Migration, Remittances and Development”, Organisation for Economic Co-operation and Development (OECD), 2005, ISBN-92-64-013881 
Appendix A: Regional Price Indices

\begin{tabular}{lcccccccc} 
Year Region & \multicolumn{7}{c}{ Expenditure Group } \\
\cline { 2 - 9 } & Food & Shelter & $\begin{array}{c}\text { HH } \\
\text { Operation \& } \\
\text { Furnishing }\end{array}$ & $\begin{array}{c}\text { Clothing Transpor- } \\
\text { tation }\end{array}$ & $\begin{array}{c}\text { Personal \& } \\
\text { Health Care }\end{array}$ & $\begin{array}{c}\text { Recreation, } \\
\text { Education \& } \\
\text { Reading Mat. }\end{array}$ & $\begin{array}{c}\text { Tobacco \& } \\
\text { Alcoholic } \\
\text { Beverages }\end{array}$ \\
\hline $\mathbf{1 9 9 2}$ Atlantic & 98.2 & 80.4 & 98.1 & 96.5 & 75.9 & 88.7 & 101.3 & 104.5 \\
$\mathbf{1 9 9 2}$ Quebec & 97.8 & 72.0 & 96.7 & 99.7 & 90.1 & 90.7 & 100.1 & 101.1 \\
$\mathbf{1 9 9 2}$ Ontario & 100.0 & 100.0 & 100.0 & 100.0 & 100.0 & 100.0 & 100.0 & 100.0 \\
$\mathbf{1 9 9 2}$ Prairies & 98.6 & 75.1 & 92.1 & 102.8 & 77.5 & 92.2 & 94.6 & 95.1 \\
$\mathbf{1 9 9 2}$ BC & 104.7 & 102.0 & 99.2 & 99.8 & 97.9 & 88.0 & 97.1 & 104.4 \\
\hline $\mathbf{1 9 9 6}$ Atlantic & 109.7 & 84.1 & 106.0 & 101.3 & 90.0 & 101.9 & 104.5 & 90.2 \\
$\mathbf{1 9 9 6}$ Quebec & 102.8 & 75.5 & 101.1 & 97.9 & 92.8 & 102.6 & 97.1 & 72.7 \\
$\mathbf{1 9 9 6}$ Ontario & 105.4 & 108.1 & 105.4 & 105.3 & 112.1 & 98.7 & 104.1 & 73.8 \\
$\mathbf{1 9 9 6}$ Prairies & 104.0 & 79.0 & 95.2 & 105.2 & 80.7 & 94.4 & 95.7 & 89.8 \\
$\mathbf{1 9 9 6}$ BC & 114.3 & 109.9 & 102.8 & 103.4 & 129.9 & 92.2 & 101.3 & 100.4 \\
\hline
\end{tabular}

Source: Pendakur (2001), Didukh (2001), and Browning and Thomas $(1998,1999)$

Note: Base Ontario, 1992.

Prices variables used for eight (out of ten) commodity groups (1. Food, 2. Shelter, 3. Household Operations and Furnishing, 4. Clothing, 5. Transportation, 6. Personal and Health Care, 7. Recreation, Education and Reading Material , 8. Tobacco and Alcoholic Beverages) included in this study are Consumer Price Indices that vary through time and across five regions (Atlantic Provinces, Quebec, Ontario, Prairies, and British Columbia) and are assumed to be fixed within the regions. For the other two expenditure groups (9. Transfers to Persons Outside the Household, and 10. Transfers to Charity) we computed prices indices based on the CPIs of the eight commodity groups mentioned before. We argue that the value of one remitted dollar to a person outside the household equals to the forgone consumption of the household for that dollar. Thus, we calculated for each household in our sample the CPIs of Transfers to Persons as sum of the CPIs of the eight expenditure groups presented above, weighted by the respective share of the expenditure group in total expenditures. Charitable donations are tax deductible. Thus, the price for one dollar donated to charity equals to value of forgone consumption minus the tax deduction received for the donation of the one dollar. The CPIs for Transfers to Charity are computed by the following formula $C P I_{\text {chaor }, i}=100+\left(C P I_{\text {poh }, i}-100\right) \times\left(1-\right.$ Taxr $\left._{i}\right)$. Where: $C P I_{\text {chaor }, i}$ is the CPI of Transfers to Charity for the $\left(\mathrm{i}^{\text {th }}\right)$ household; $C P I_{p o h, i}$ is the CPI of Transfers to Persons for the $\left(\mathrm{i}^{\text {th }}\right)$ household; and Taxr ${ }_{i}$ stands for the tax rate applicable for the $\left(\mathrm{i}^{\text {th }}\right)$ household. ${ }^{26}$

\footnotetext{
${ }^{26}$ The tax rates are computed distinctively for each household through a combination of the federal and provincial tax rates. Tax rates are progressive. Data for tax rates are from Statistics Canada.
} 
Appendix B

Table B-1: Expenditure Elasticities Calculated from LA/AIDS, Unrestricted (1992/1996)

\begin{tabular}{|c|c|c|c|c|c|c|c|}
\hline \multirow{3}{*}{$\begin{array}{l}\text { Population } \\
\text { Group }\end{array}$} & \multirow{3}{*}{$\begin{array}{l}\text { Expenditure } \\
\text { Group }\end{array}$} & \multicolumn{3}{|c|}{ Uncontrolled } & \multicolumn{3}{|c|}{ Controlled } \\
\hline & & \multicolumn{3}{|c|}{ Income Group } & \multicolumn{3}{|c|}{ Income Group } \\
\hline & & all & top $Y / 2$ & bottom Y/2 & all & top $Y / 2$ & bottom $Y / 2$ \\
\hline \multirow[t]{10}{*}{ Canadian } & Food & 0.74 & 0.67 & 0.72 & 0.64 & 0.59 & 0.63 \\
\hline & Shelter & 0.68 & 0.70 & 0.64 & 0.64 & 0.69 & 0.62 \\
\hline & HH op\&fur & 1.02 & 1.06 & 0.96 & 1.02 & 1.09 & 0.99 \\
\hline & Cloth & 1.30 & 1.20 & 1.30 & 1.21 & 1.19 & 1.25 \\
\hline & Transport & 1.58 & 1.49 & 1.89 & 1.63 & 1.46 & 1.87 \\
\hline & Heath\&Pers.Care & 0.85 & 0.77 & 0.90 & 0.88 & 0.76 & 1.01 \\
\hline & Recreation & 1.41 & 1.32 & 1.42 & 1.29 & 1.28 & 1.29 \\
\hline & Tabacco\&Alcohol & 0.95 & 0.88 & 1.11 & 0.95 & 1.02 & 1.00 \\
\hline & Transf to pers & 1.07 & 1.27 & 1.19 & 1.83 & 1.73 & 1.82 \\
\hline & Transf to char & 0.60 & 0.48 & 0.47 & 0.96 & 0.70 & 0.94 \\
\hline N.American \& & Food & 0.77 & 0.73 & 0.69 & 0.65 & 0.66 & 0.57 \\
\hline \multirow[t]{9}{*}{ W.European } & Shelter & 0.68 & 0.70 & 0.67 & 0.66 & 0.66 & 0.69 \\
\hline & HH op\&fur & 1.07 & 1.16 & 1.03 & 1.07 & 1.18 & 1.02 \\
\hline & Cloth & 1.31 & 1.27 & 1.20 & 1.14 & 1.18 & 1.15 \\
\hline & Transport & 1.44 & 1.27 & 1.66 & 1.46 & 1.31 & 1.65 \\
\hline & Heath\&Pers.Care & 0.79 & 0.74 & 0.77 & 0.77 & 0.59 & 0.87 \\
\hline & Recreation & 1.50 & 1.46 & 1.63 & 1.30 & 1.32 & 1.46 \\
\hline & Tabacco\&Alcohol & 1.01 & 0.67 & 1.15 & 0.94 & 0.80 & 0.98 \\
\hline & Transf to pers & 1.29 & 1.43 & 1.67 & 2.21 & 2.12 & 2.16 \\
\hline & Transf to char & 0.78 & 0.65 & 1.03 & 1.19 & 0.78 & 1.26 \\
\hline \multirow{10}{*}{$\begin{array}{c}\text { S\&E } \\
\text { European }\end{array}$} & Food & 0.77 & 0.69 & 0.72 & 0.68 & 0.63 & 0.72 \\
\hline & Shelter & 0.60 & 0.62 & 0.53 & 0.55 & 0.66 & 0.45 \\
\hline & HH op\&fur & 0.99 & 0.99 & 1.01 & 0.96 & 1.00 & 1.02 \\
\hline & Cloth & 1.29 & 1.25 & 1.14 & 1.11 & 1.21 & 1.04 \\
\hline & Transport & 1.57 & 1.52 & 2.04 & 1.55 & 1.44 & 1.78 \\
\hline & Heath\&Pers.Care & 0.95 & 0.87 & 0.91 & 1.03 & 0.88 & 1.02 \\
\hline & Recreation & 1.47 & 1.35 & 1.40 & 1.25 & 1.23 & 1.21 \\
\hline & Tabacco\&Alcohol & 1.22 & 1.12 & 1.39 & 1.18 & 1.33 & 1.09 \\
\hline & Transf to pers & 1.01 & 1.11 & 1.09 & 2.04 & 1.58 & 2.24 \\
\hline & Transf to char & 0.54 & 0.97 & 0.32 & 1.25 & 1.09 & 1.18 \\
\hline \multirow{2}{*}{$\begin{array}{l}\text { Chinese, } \\
\text { Asian \& Oc. }\end{array}$} & Transf to pers & 1.09 & 1.12 & 1.09 & 1.09 & 1.12 & 1.09 \\
\hline & Transf to char & 0.79 & 0.76 & 0.78 & 0.77 & 0.74 & 0.77 \\
\hline
\end{tabular}


Table B-2: Expenditure Elasticities Calculated from LA/AIDS, Restricted (1992/1996)

\begin{tabular}{|c|c|c|c|c|c|c|c|}
\hline \multirow{3}{*}{$\begin{array}{l}\text { Population } \\
\text { Group }\end{array}$} & \multirow{3}{*}{$\begin{array}{l}\text { Expenditure } \\
\text { Group }\end{array}$} & \multirow{2}{*}{\multicolumn{3}{|c|}{ Uncontrolled }} & \multirow{2}{*}{\multicolumn{3}{|c|}{$\frac{\text { Controlled }}{\text { Income Groun }}$}} \\
\hline & & Income Group & & & & & \\
\hline & & all & top $Y / 2$ & bottom Y/2 & all & top Y/2 & bottom Y/2 \\
\hline \multirow[t]{10}{*}{ Canadian } & Food & 0.77 & 0.66 & 0.74 & 0.63 & 0.57 & 0.63 \\
\hline & Shelter & 0.67 & 0.76 & 0.63 & 0.69 & 0.77 & 0.66 \\
\hline & HH op\&fur & 1.04 & 1.03 & 0.97 & 0.99 & 1.04 & 0.96 \\
\hline & Cloth & 1.33 & 1.18 & 1.31 & 1.19 & 1.14 & 1.23 \\
\hline & Transport & 1.53 & 1.53 & 1.87 & 1.64 & 1.53 & 1.88 \\
\hline & Heath\&Pers.Care & 0.85 & 0.72 & 0.91 & 0.85 & 0.69 & 0.99 \\
\hline & Recreation & 1.43 & 1.26 & 1.44 & 1.24 & 1.18 & 1.25 \\
\hline & Tabacco\&Alcohol & 0.91 & 0.79 & 1.08 & 0.90 & 0.92 & 0.93 \\
\hline & Transf to pers & 1.09 & 1.25 & 1.20 & 1.82 & 1.69 & 1.80 \\
\hline & Transf to char & 0.67 & 0.56 & 0.50 & 0.97 & 0.72 & 0.93 \\
\hline N.American \& & Food & 0.78 & 0.72 & 0.70 & 0.65 & 0.65 & 0.57 \\
\hline \multirow[t]{9}{*}{ W.European } & Shelter & 0.67 & 0.72 & 0.66 & 0.67 & 0.70 & 0.71 \\
\hline & HH op\&fur & 1.08 & 1.15 & 1.03 & 1.07 & 1.17 & 1.01 \\
\hline & Cloth & 1.31 & 1.25 & 1.20 & 1.14 & 1.16 & 1.15 \\
\hline & Transport & 1.44 & 1.28 & 1.67 & 1.45 & 1.31 & 1.63 \\
\hline & Heath\&Pers.Care & 0.79 & 0.72 & 0.76 & 0.76 & 0.58 & 0.86 \\
\hline & Recreation & 1.50 & 1.43 & 1.62 & 1.29 & 1.29 & 1.45 \\
\hline & Tabacco\&Alcohol & 1.00 & 0.68 & 1.17 & 0.94 & 0.81 & 1.01 \\
\hline & Transf to pers & 1.29 & 1.43 & 1.66 & 2.21 & 2.10 & 2.15 \\
\hline & Transf to char & 0.79 & 0.66 & 1.02 & 1.18 & 0.77 & 1.24 \\
\hline S\&E & Food & 0.77 & 0.69 & 0.71 & 0.69 & 0.63 & 0.71 \\
\hline \multirow{9}{*}{ European } & Shelter & 0.59 & 0.63 & 0.53 & 0.54 & 0.66 & 0.47 \\
\hline & HH op\&fur & 1.00 & 0.99 & 1.03 & 0.97 & 1.00 & 1.00 \\
\hline & Cloth & 1.28 & 1.25 & 1.11 & 1.11 & 1.20 & 1.00 \\
\hline & Transport & 1.59 & 1.52 & 2.02 & 1.56 & 1.44 & 1.79 \\
\hline & Heath\&Pers.Care & 0.97 & 0.88 & 0.94 & 1.04 & 0.90 & 1.03 \\
\hline & Recreation & 1.49 & 1.35 & 1.43 & 1.27 & 1.23 & 1.22 \\
\hline & Tabacco\&Alcohol & 1.20 & 1.12 & 1.35 & 1.15 & 1.31 & 1.05 \\
\hline & Transf to pers & 0.98 & 1.06 & 1.08 & 2.00 & 1.54 & 2.21 \\
\hline & Transf to char & 0.56 & 0.97 & 0.40 & 1.28 & 1.11 & 1.23 \\
\hline \multirow{2}{*}{$\begin{array}{c}\text { Chinese, } \\
\text { Asian \& Oc. }\end{array}$} & Transf to pers & 1.09 & 1.12 & 1.09 & 1.09 & 1.12 & 1.09 \\
\hline & Transf to char & 0.79 & 0.76 & 0.78 & 0.77 & 0.74 & 0.77 \\
\hline
\end{tabular}




\section{Appendix C}

\section{Table C-1: Regression Equation Coefficients (OLS) Predicting the Expenditure Share of Transfers to Persons, 1992/1996}

\begin{tabular}{|c|c|c|c|c|c|c|c|c|}
\hline & \multicolumn{2}{|c|}{ Canadian } & \multicolumn{2}{|c|}{ N.Am.\&W.Eu. } & \multicolumn{2}{|c|}{ S\&E European } & \multicolumn{2}{|c|}{ Ch.,Asian\&Oc. } \\
\hline & Uncontrolled & Controlled & Uncontrolled & Controlled & Uncontrolled & Controlled & Uncontrolled & Controlled \\
\hline Log of Total Expenditures & $\begin{array}{c}2.74 \mathrm{e}-03 \\
{[1.47 \mathrm{e}-03]^{\star}}\end{array}$ & $\begin{array}{c}3.15 \mathrm{e}-02 \\
{[2.11 \mathrm{e}-03]^{\star * *}}\end{array}$ & $\begin{array}{c}1.44 \mathrm{e}-02 \\
{[5.79 \mathrm{e}-03]^{\star *}}\end{array}$ & $\begin{array}{c}6.02 \mathrm{e}-02 \\
{[1.10 \mathrm{e}-02]^{\star * *}}\end{array}$ & $\begin{array}{c}4.26 \mathrm{e}-04 \\
{[8.76 \mathrm{e}-03]}\end{array}$ & $\begin{array}{c}5.42 \mathrm{e}-02 \\
{[1.42 \mathrm{e}-02]^{\star \star *}}\end{array}$ & & \\
\hline Log of Total Transfers & & & & & & & $\begin{array}{c}7.78 \mathrm{e}-02 \\
{[1.05 \mathrm{e}-02]^{\star \star *}}\end{array}$ & $\begin{array}{c}9.33 \mathrm{e}-02 \\
{[1.02 \mathrm{e}-02]^{\star \star \star}}\end{array}$ \\
\hline Log of Price for Food & $\begin{array}{c}1.04 \mathrm{e}-01 \\
{[4.47 \mathrm{e}-02]^{\star \star}}\end{array}$ & $\begin{array}{c}1.11 \mathrm{e}-01 \\
{[4.19 \mathrm{e}-02]^{\star \star \star}}\end{array}$ & $\begin{array}{c}3.53 \mathrm{e}-02 \\
{[1.80 \mathrm{e}-01]}\end{array}$ & $\begin{array}{c}1.01 \mathrm{e}-01 \\
{[1.71 \mathrm{e}-01]}\end{array}$ & $\begin{array}{l}-2.76 \mathrm{e}-01 \\
{[4.15 \mathrm{e}-01]}\end{array}$ & $\begin{array}{l}-1.84 \mathrm{e}-01 \\
{[3.86 \mathrm{e}-01]}\end{array}$ & & \\
\hline Log of Price for Shelter & $\begin{array}{c}5.80 \mathrm{e}-02 \\
{[1.02 \mathrm{e}-02]^{\star * *}}\end{array}$ & $\begin{array}{c}2.40 \mathrm{e}-02 \\
{[1.00 \mathrm{e}-02]^{\star \star}}\end{array}$ & $\begin{array}{c}1.10 \mathrm{e}-01 \\
{[5.14 \mathrm{e}-02]^{\star *}}\end{array}$ & $\begin{array}{c}9.43 e-02 \\
{[4.78 \mathrm{e}-02]^{\star *}}\end{array}$ & $\begin{array}{c}3.08 \mathrm{e}-02 \\
{[1.41 \mathrm{e}-01]}\end{array}$ & $\begin{array}{c}8.13 e-02 \\
{[1.37 e-01]}\end{array}$ & & \\
\hline Log of Price for $\mathrm{HH}$ op\&furn & $\begin{array}{l}-7.21 \mathrm{e}-02 \\
{[1.26 \mathrm{e}-01]}\end{array}$ & $\begin{array}{c}-2.09 \mathrm{e}-01 \\
{[1.17 \mathrm{e}-01]^{\star}}\end{array}$ & $\begin{array}{c}2.97 \mathrm{e}-01 \\
{[4.79 \mathrm{e}-01]}\end{array}$ & $\begin{array}{c}9.96 \mathrm{e}-02 \\
{[4.56 \mathrm{e}-01]}\end{array}$ & $\begin{array}{c}8.51 \mathrm{e}-01 \\
{[1.30 \mathrm{e}+00]}\end{array}$ & $\begin{array}{c}5.87 e-02 \\
{[1.15 e+00]}\end{array}$ & & \\
\hline Log of Price for Clothing & $\begin{array}{c}8.18 \mathrm{e}-02 \\
{[5.65 \mathrm{e}-02]}\end{array}$ & $\begin{array}{c}1.83 \mathrm{e}-02 \\
{[5.30 \mathrm{e}-02]}\end{array}$ & $\begin{array}{c}2.95 \mathrm{e}-01 \\
{[2.17 \mathrm{e}-01]}\end{array}$ & $\begin{array}{c}1.15 \mathrm{e}-01 \\
{[2.15 \mathrm{e}-01]}\end{array}$ & $\begin{array}{c}5.85 \mathrm{e}-01 \\
{[5.89 \mathrm{e}-01]}\end{array}$ & $\begin{array}{c}1.23 \mathrm{e}-01 \\
{[5.55 \mathrm{e}-01]}\end{array}$ & & \\
\hline Log of Price for Transportation & $\begin{array}{c}-3.38 \mathrm{e}-02 \\
{[8.39 \mathrm{e}-03]^{\star \star *}}\end{array}$ & $\begin{array}{c}-7.93 \mathrm{e}-02 \\
{[8.12 \mathrm{e}-03]^{\star \star \star}}\end{array}$ & $\begin{array}{l}-1.43 e-02 \\
{[4.07 e-02]}\end{array}$ & $\begin{array}{l}-3.95 e-02 \\
{[3.83 e-02]}\end{array}$ & $\begin{array}{c}3.54 \mathrm{e}-02 \\
{[7.15 \mathrm{e}-02]}\end{array}$ & $\begin{array}{c}4.92 \mathrm{e}-02 \\
{[6.88 \mathrm{e}-02]}\end{array}$ & & \\
\hline Log of Price for Health\&Pers. Care & $\begin{array}{c}6.72 \mathrm{e}-03 \\
{[2.30 \mathrm{e}-02]}\end{array}$ & $\begin{array}{c}2.05 \mathrm{e}-02 \\
{[2.15 \mathrm{e}-02]}\end{array}$ & $\begin{array}{l}-5.52 \mathrm{e}-02 \\
{[8.87 \mathrm{e}-02]}\end{array}$ & $\begin{array}{l}-3.11 \mathrm{e}-02 \\
{[8.39 \mathrm{e}-02]}\end{array}$ & $\begin{array}{l}-2.94 \mathrm{e}-01 \\
{[2.39 \mathrm{e}-01]}\end{array}$ & $\begin{array}{l}-2.36 e-01 \\
{[2.07 e-01]}\end{array}$ & & \\
\hline Log of Price for Recreation & $\begin{array}{c}2.59 \mathrm{e}-02 \\
{[8.92 \mathrm{e}-02]}\end{array}$ & $\begin{array}{c}1.20 \mathrm{e}-01 \\
{[8.31 \mathrm{e}-02]}\end{array}$ & $\begin{array}{l}-2.71 e-01 \\
{[3.37 e-01]}\end{array}$ & $\begin{array}{c}-1.34 \mathrm{e}-01 \\
{[3.22 \mathrm{e}-01]}\end{array}$ & $\begin{array}{l}-7.25 \mathrm{e}-01 \\
{[9.71 \mathrm{e}-01]}\end{array}$ & $\begin{array}{l}-1.32 \mathrm{e}-01 \\
{[8.50 \mathrm{e}-01]}\end{array}$ & & \\
\hline Log of Price for Tabacco\&Alcohol & $\begin{array}{c}1.70 \mathrm{e}-03 \\
{[1.20 \mathrm{e}-02]}\end{array}$ & $\begin{array}{l}-1.06 \mathrm{e}-02 \\
{[1.14 \mathrm{e}-02]}\end{array}$ & $\begin{array}{c}4.75 \mathrm{e}-02 \\
{[4.47 \mathrm{e}-02]}\end{array}$ & $\begin{array}{c}3.30 \mathrm{e}-02 \\
{[4.40 \mathrm{e}-02]}\end{array}$ & $\begin{array}{c}4.13 \mathrm{e}-02 \\
{[1.24 \mathrm{e}-01]}\end{array}$ & $\begin{array}{c}-2.66 \mathrm{e}-02 \\
{[1.17 \mathrm{e}-01]}\end{array}$ & & \\
\hline Log of Price for Transf. to Persons & $\begin{array}{c}1.73 e-01 \\
{[1.32 e-01]}\end{array}$ & $\begin{array}{c}2.41 \mathrm{e}-01 \\
{[1.23 \mathrm{e}-01]^{\star \star}}\end{array}$ & $\begin{array}{c}1.40 \mathrm{e}-01 \\
{[5.33 \mathrm{e}-01]}\end{array}$ & $\begin{array}{c}-1.05 \mathrm{e}-01 \\
{[4.96 \mathrm{e}-01]}\end{array}$ & $\begin{array}{c}3.68 \mathrm{e}-01 \\
{[6.69 \mathrm{e}-01]}\end{array}$ & $\begin{array}{c}4.54 \mathrm{e}-01 \\
{[6.73 \mathrm{e}-01]}\end{array}$ & $\begin{array}{c}3.64 \mathrm{e}+00 \\
{[2.75 \mathrm{e}+00]}\end{array}$ & $\begin{array}{c}2.63 e+00 \\
{[2.57 e+00]}\end{array}$ \\
\hline Log of Price for Transf. to Charity & $\begin{array}{c}-3.43 e-01 \\
{[1.96 e-01]^{\star}}\end{array}$ & $\begin{array}{l}-1.58 \mathrm{e}-01 \\
{[1.83 \mathrm{e}-01]}\end{array}$ & $\begin{array}{l}-4.74 \mathrm{e}-01 \\
{[8.69 \mathrm{e}-01]}\end{array}$ & $\begin{array}{c}5.65 \mathrm{e}-02 \\
{[7.85 \mathrm{e}-01]}\end{array}$ & $\begin{array}{l}-8.94 \mathrm{e}-01 \\
{[9.83 \mathrm{e}-01]}\end{array}$ & $\begin{array}{c}-9.01 e-01 \\
{[9.48 e-01]}\end{array}$ & $\begin{array}{c}-4.98 e+00 \\
{[3.96 e+00]}\end{array}$ & $\begin{array}{l}-3.55 e+00 \\
{[3.71 e+00]}\end{array}$ \\
\hline Female & & $\begin{array}{l}-6.06 \mathrm{e}-04 \\
{[1.09 \mathrm{e}-03]}\end{array}$ & & $\begin{array}{c}3.77 \mathrm{e}-03 \\
{[5.21 \mathrm{e}-03]}\end{array}$ & & $\begin{array}{c}1.41 \mathrm{e}-02 \\
{[8.08 \mathrm{e}-03]^{\star}}\end{array}$ & & $\begin{array}{l}-2.40 \mathrm{e}-02 \\
{[2.66 \mathrm{e}-02]}\end{array}$ \\
\hline Age & & $\begin{array}{c}-1.44 \mathrm{e}-03 \\
{[3.16 \mathrm{e}-04]^{\star \star \star}}\end{array}$ & & $\begin{array}{l}-7.00 \mathrm{e}-04 \\
{[1.45 \mathrm{e}-03]}\end{array}$ & & $\begin{array}{c}-5.01 \mathrm{e}-03 \\
{[1.96 \mathrm{e}-03]^{\star \star}}\end{array}$ & & $\begin{array}{l}-3.57 \mathrm{e}-04 \\
{[6.74 \mathrm{e}-03]}\end{array}$ \\
\hline Age - squared & & $\begin{array}{c}2.40 \mathrm{e}-05 \\
{[3.40 \mathrm{e}-06]^{\star \star \star}}\end{array}$ & & $\begin{array}{c}1.65 \mathrm{e}-05 \\
{[1.52 \mathrm{e}-05]}\end{array}$ & & $\begin{array}{c}6.34 \mathrm{e}-05 \\
{[2.07 \mathrm{e}-05]^{\star \star *}}\end{array}$ & & $\begin{array}{l}-5.79 \mathrm{e}-05 \\
{[6.48 \mathrm{e}-05]}\end{array}$ \\
\hline Education & & $\begin{array}{l}-2.05 \mathrm{e}-03 \\
{[2.74 \mathrm{e}-03]}\end{array}$ & & $\begin{array}{l}-2.26 \mathrm{e}-02 \\
{[1.40 \mathrm{e}-02]}\end{array}$ & & $\begin{array}{c}-2.49 \mathrm{e}-02 \\
{[1.28 \mathrm{e}-02]^{*}}\end{array}$ & & $\begin{array}{c}3.00 \mathrm{e}-02 \\
{[5.19 \mathrm{e}-02]}\end{array}$ \\
\hline No. Of Persons a Member & & $\begin{array}{c}-1.28 \mathrm{e}-02 \\
{[5.86 \mathrm{e}-04]^{\star \star \star}}\end{array}$ & & $\begin{array}{c}-2.10 \mathrm{e}-02 \\
{[2.58 \mathrm{e}-03]^{\star \star \star}}\end{array}$ & & $\begin{array}{c}-1.70 \mathrm{e}-02 \\
{[3.62 \mathrm{e}-03]^{\star \star \star}}\end{array}$ & & $\begin{array}{c}-2.68 \mathrm{e}-02 \\
{[1.20 \mathrm{e}-02]^{\star *}}\end{array}$ \\
\hline House Ownership & & $\begin{array}{l}-1.98 e-03 \\
{[1.33 e-03]}\end{array}$ & & $\begin{array}{c}1.23 \mathrm{e}-03 \\
{[6.09 \mathrm{e}-03]}\end{array}$ & & $\begin{array}{l}-5.91 \mathrm{e}-03 \\
{[8.17 \mathrm{e}-03]}\end{array}$ & & $\begin{array}{c}-7.31 \mathrm{e}-02 \\
{[3.35 \mathrm{e}-02]^{\star *}}\end{array}$ \\
\hline Net change in A\&L & & $\begin{array}{c}-2.24 \mathrm{e}-07 \\
{[8.84 \mathrm{e}-08]^{\star *}}\end{array}$ & & $\begin{array}{l}-8.70 \mathrm{e}-08 \\
{[2.68 \mathrm{e}-07]}\end{array}$ & & $\begin{array}{c}1.79 \mathrm{e}-07 \\
{[3.59 \mathrm{e}-07]}\end{array}$ & & $\begin{array}{l}-5.59 \mathrm{e}-07 \\
{[7.91 \mathrm{e}-07]}\end{array}$ \\
\hline Constant & $\begin{array}{c}5.62 \mathrm{e}-03 \\
{[4.01 \mathrm{e}-01]}\end{array}$ & $\begin{array}{c}-4.59 \mathrm{e}-01 \\
{[3.77 \mathrm{e}-01]}\end{array}$ & $\begin{array}{c}-5.45 e-01 \\
{[1.64 e+00]}\end{array}$ & $\begin{array}{l}-1.10 e+00 \\
{[1.55 e+00]}\end{array}$ & $\begin{array}{c}1.31 \mathrm{e}+00 \\
{[3.50 \mathrm{e}+00]}\end{array}$ & $\begin{array}{c}3.16 \mathrm{e}+00 \\
{[3.50 \mathrm{e}+00]}\end{array}$ & $\begin{array}{c}6.72 \mathrm{e}+00 \\
{[5.68 \mathrm{e}+00]}\end{array}$ & $\begin{array}{c}5.10 e+00 \\
{[5.35 e+00]}\end{array}$ \\
\hline Observations & 13970 & 13970 & 1176 & 1176 & 632 & 632 & 632 & 632 \\
\hline R-squared & 0.01 & 0.13 & 0.02 & 0.15 & 0.02 & 0.18 & 0.11 & 0.18 \\
\hline
\end{tabular}




\section{Table C-2: Regression Equation Coefficients (OLS) Predicting the Expenditure Share of Transfers to Charity, 1992/1996}

\begin{tabular}{|c|c|c|c|c|c|c|c|c|}
\hline & \multicolumn{2}{|c|}{ Canadian } & \multicolumn{2}{|c|}{ N.Am.\&W.Eu. } & \multicolumn{2}{|c|}{ S\&E European } & \multicolumn{2}{|c|}{ Ch.,Asian\&Oc. } \\
\hline & Uncontrolled & Controlled & Uncontrolled & Controlled & Uncontrolled & Controlled & Uncontrolled & Controlled \\
\hline Log of Total Expenditures & $\begin{array}{c}-5.66 \mathrm{e}-03 \\
{[5.52 \mathrm{e}-04]^{\star \star \star}}\end{array}$ & $\begin{array}{c}-1.00 \mathrm{e}-03 \\
{[7.11 \mathrm{e}-04]}\end{array}$ & $\begin{array}{c}-4.52 \mathrm{e}-03 \\
{[2.41 \mathrm{e}-03]^{\star}}\end{array}$ & $\begin{array}{c}1.98 \mathrm{e}-03 \\
{[3.40 \mathrm{e}-03]}\end{array}$ & $\begin{array}{c}-7.06 \mathrm{e}-03 \\
{[2.98 \mathrm{e}-03]^{\star \star}}\end{array}$ & $\begin{array}{c}3.80 \mathrm{e}-03 \\
{[4.26 \mathrm{e}-03]}\end{array}$ & & \\
\hline Log of Total Transfers & & & & & & & $\begin{array}{c}-7.78 \mathrm{e}-02 \\
{[1.05 \mathrm{e}-02]^{\star \star \star}}\end{array}$ & $\begin{array}{c}-9.33 \mathrm{e}-02 \\
{[1.02 \mathrm{e}-02]^{\star \star \star}}\end{array}$ \\
\hline Log of Price for Food & $\begin{array}{c}1.06 \mathrm{e}-01 \\
{[2.02 \mathrm{e}-02]^{\star \star \star}}\end{array}$ & $\begin{array}{c}9.14 \mathrm{e}-02 \\
{[1.95 \mathrm{e}-02]^{\star \star \star}}\end{array}$ & $\begin{array}{c}-4.01 \mathrm{e}-02 \\
{[6.64 \mathrm{e}-02]}\end{array}$ & $\begin{array}{l}-2.73 e-03 \\
{[6.47 e-02]}\end{array}$ & $\begin{array}{c}5.53 \mathrm{e}-02 \\
{[1.53 \mathrm{e}-01]}\end{array}$ & $\begin{array}{c}3.65 \mathrm{e}-02 \\
{[1.50 \mathrm{e}-01]}\end{array}$ & & \\
\hline Log of Price for Shelter & $\begin{array}{c}5.16 \mathrm{e}-02 \\
{[4.54 \mathrm{e}-03]^{\star \star \star}}\end{array}$ & $\begin{array}{c}4.21 \mathrm{e}-02 \\
{[4.29 \mathrm{e}-03]^{\star \star \star}}\end{array}$ & $\begin{array}{c}5.95 \mathrm{e}-03 \\
{[1.98 \mathrm{e}-02]}\end{array}$ & $\begin{array}{c}5.25 \mathrm{e}-03 \\
{[1.90 \mathrm{e}-02]}\end{array}$ & $\begin{array}{c}3.48 \mathrm{e}-03 \\
{[4.44 \mathrm{e}-02]}\end{array}$ & $\begin{array}{c}1.06 \mathrm{e}-02 \\
{[4.47 \mathrm{e}-02]}\end{array}$ & & \\
\hline Log of Price for $\mathrm{HH}$ op\&furn & $\begin{array}{c}-2.60 \mathrm{e}-01 \\
{[5.70 \mathrm{e}-02]^{\star * *}}\end{array}$ & $\begin{array}{c}-2.55 \mathrm{e}-01 \\
{[5.54 \mathrm{e}-02]^{\star \star \star}}\end{array}$ & $\begin{array}{c}1.80 \mathrm{e}-01 \\
{[2.10 \mathrm{e}-01]}\end{array}$ & $\begin{array}{c}6.48 \mathrm{e}-02 \\
{[2.08 \mathrm{e}-01]}\end{array}$ & $\begin{array}{c}3.15 \mathrm{e}-01 \\
{[4.76 \mathrm{e}-01]}\end{array}$ & $\begin{array}{c}2.45 \mathrm{e}-01 \\
{[4.40 \mathrm{e}-01]}\end{array}$ & & \\
\hline Log of Price for Clothing & $\begin{array}{l}-1.68 \mathrm{e}-02 \\
{[2.55 \mathrm{e}-02]}\end{array}$ & $\begin{array}{l}-2.83 e-02 \\
{[2.46 e-02]}\end{array}$ & $\begin{array}{c}2.07 \mathrm{e}-01 \\
{[1.10 \mathrm{e}-01]^{\star}}\end{array}$ & $\begin{array}{c}1.03 e-01 \\
{[1.09 e-01]}\end{array}$ & $\begin{array}{c}4.03 \mathrm{e}-01 \\
{[2.76 \mathrm{e}-01]}\end{array}$ & $\begin{array}{c}3.21 \mathrm{e}-01 \\
{[2.48 \mathrm{e}-01]}\end{array}$ & & \\
\hline Log of Price for Transportation & $\begin{array}{c}-3.93 e-02 \\
{[3.90 e-03]^{\star \star \star}}\end{array}$ & $\begin{array}{c}-3.64 \mathrm{e}-02 \\
{[3.85 \mathrm{e}-03]^{\star \star *}}\end{array}$ & $\begin{array}{c}-2.57 \mathrm{e}-02 \\
{[1.46 \mathrm{e}-02]^{\star}}\end{array}$ & $\begin{array}{l}-8.58 \mathrm{e}-03 \\
{[1.57 \mathrm{e}-02]}\end{array}$ & $\begin{array}{l}-1.52 \mathrm{e}-02 \\
{[2.59 \mathrm{e}-02]}\end{array}$ & $\begin{array}{l}-7.14 \mathrm{e}-03 \\
{[2.67 \mathrm{e}-02]}\end{array}$ & & \\
\hline Log of Price for Health\&Pers. Care & $\begin{array}{c}5.39 \mathrm{e}-02 \\
{[1.05 \mathrm{e}-02]^{\star \star *}}\end{array}$ & $\begin{array}{c}4.95 \mathrm{e}-02 \\
{[1.02 \mathrm{e}-02]^{\star \star *}}\end{array}$ & $\begin{array}{c}2.73 e-02 \\
{[4.17 e-02]}\end{array}$ & $\begin{array}{c}3.82 \mathrm{e}-02 \\
{[4.00 \mathrm{e}-02]}\end{array}$ & $\begin{array}{c}2.60 \mathrm{e}-02 \\
{[6.02 \mathrm{e}-02]}\end{array}$ & $\begin{array}{c}7.97 \mathrm{e}-03 \\
{[5.75 \mathrm{e}-02]}\end{array}$ & & \\
\hline Log of Price for Recreation & $\begin{array}{c}1.71 \mathrm{e}-01 \\
{[4.01 \mathrm{e}-02]^{\star * *}}\end{array}$ & $\begin{array}{c}1.79 \mathrm{e}-01 \\
{[3.89 \mathrm{e}-02]^{\star * *}}\end{array}$ & $\begin{array}{c}-1.22 \mathrm{e}-01 \\
{[1.47 \mathrm{e}-01]}\end{array}$ & $\begin{array}{l}-6.21 \mathrm{e}-02 \\
{[1.44 \mathrm{e}-01]}\end{array}$ & $\begin{array}{l}-4.09 \mathrm{e}-01 \\
{[3.54 \mathrm{e}-01]}\end{array}$ & $\begin{array}{l}-3.55 e-01 \\
{[3.29 e-01]}\end{array}$ & & \\
\hline Log of Price for Tabacco\&Alcohol & $\begin{array}{c}-1.42 \mathrm{e}-02 \\
{[5.30 \mathrm{e}-03]^{\star \star \star}}\end{array}$ & $\begin{array}{c}-1.36 \mathrm{e}-02 \\
{[5.12 \mathrm{e}-03]^{\star \star *}}\end{array}$ & $\begin{array}{c}4.10 \mathrm{e}-02 \\
{[2.34 \mathrm{e}-02]^{\star}}\end{array}$ & $\begin{array}{c}2.48 \mathrm{e}-02 \\
{[2.33 \mathrm{e}-02]}\end{array}$ & $\begin{array}{c}6.67 \mathrm{e}-02 \\
{[4.97 \mathrm{e}-02]}\end{array}$ & $\begin{array}{c}5.87 \mathrm{e}-02 \\
{[4.56 \mathrm{e}-02]}\end{array}$ & & \\
\hline Log of Price for Transf. to Persons & $\begin{array}{c}-2.58 \mathrm{e}-01 \\
{[6.93 \mathrm{e}-02]^{\star \star *}}\end{array}$ & $\begin{array}{c}-8.76 \mathrm{e}-02 \\
{[6.61 \mathrm{e}-02]}\end{array}$ & $\begin{array}{c}6.11 \mathrm{e}-01 \\
{[3.11 \mathrm{e}-01]^{*}}\end{array}$ & $\begin{array}{c}6.57 \mathrm{e}-01 \\
{[3.12 \mathrm{e}-01]^{\star \star}}\end{array}$ & $\begin{array}{l}-5.53 e-01 \\
{[3.87 e-01]}\end{array}$ & $\begin{array}{l}-4.39 \mathrm{e}-01 \\
{[3.58 \mathrm{e}-01]}\end{array}$ & $\begin{array}{l}-3.64 \mathrm{e}+00 \\
{[2.75 \mathrm{e}+00]}\end{array}$ & $\begin{array}{c}-2.63 e+00 \\
{[2.57 e+00]}\end{array}$ \\
\hline Log of Price for Transf. to Charity & $\begin{array}{c}3.54 \mathrm{e}-01 \\
{[1.02 \mathrm{e}-01]^{\star \star *}}\end{array}$ & $\begin{array}{c}1.26 \mathrm{e}-01 \\
{[9.84 \mathrm{e}-02]}\end{array}$ & $\begin{array}{c}-9.07 \mathrm{e}-01 \\
{[4.62 \mathrm{e}-01]^{*}}\end{array}$ & $\begin{array}{c}-9.83 e-01 \\
{[4.61 e-01]^{\star *}}\end{array}$ & $\begin{array}{c}7.33 \mathrm{e}-01 \\
{[5.61 \mathrm{e}-01]}\end{array}$ & $\begin{array}{c}5.88 \mathrm{e}-01 \\
{[5.17 \mathrm{e}-01]}\end{array}$ & $\begin{array}{c}4.98 \mathrm{e}+00 \\
{[3.96 \mathrm{e}+00]}\end{array}$ & $\begin{array}{c}3.55 \mathrm{e}+00 \\
{[3.71 \mathrm{e}+00]}\end{array}$ \\
\hline Female & & $\begin{array}{l}-5.97 e-04 \\
{[5.25 e-04]}\end{array}$ & & $\begin{array}{c}3.86 e-03 \\
{[2.97 e-03]}\end{array}$ & & $\begin{array}{c}2.17 \mathrm{e}-03 \\
{[3.61 \mathrm{e}-03]}\end{array}$ & & $\begin{array}{c}2.40 \mathrm{e}-02 \\
{[2.66 \mathrm{e}-02]}\end{array}$ \\
\hline Age & & $\begin{array}{c}-8.06 \mathrm{e}-04 \\
{[1.42 \mathrm{e}-04]^{\star \star \star}}\end{array}$ & & $\begin{array}{c}-1.54 \mathrm{e}-03 \\
{[7.77 \mathrm{e}-04]^{\star \star}}\end{array}$ & & $\begin{array}{c}-2.19 \mathrm{e}-03 \\
{[8.43 \mathrm{e}-04]^{\star \star \star}}\end{array}$ & & $\begin{array}{c}3.57 \mathrm{e}-04 \\
{[6.74 \mathrm{e}-03]}\end{array}$ \\
\hline Age - squared & & $\begin{array}{c}1.39 \mathrm{e}-05 \\
{[1.50 \mathrm{e}-06]^{\star \star *}}\end{array}$ & & $\begin{array}{c}2.01 \mathrm{e}-05 \\
{[7.99 \mathrm{e}-06]^{\star \star}}\end{array}$ & & $\begin{array}{c}2.92 \mathrm{e}-05 \\
{[9.10 \mathrm{e}-06]^{\star \star \star}}\end{array}$ & & $\begin{array}{c}5.79 \mathrm{e}-05 \\
{[6.48 \mathrm{e}-05]}\end{array}$ \\
\hline Education & & $\begin{array}{c}3.47 \mathrm{e}-03 \\
{[1.27 \mathrm{e}-03]^{\star * *}}\end{array}$ & & $\begin{array}{c}-2.68 \mathrm{e}-02 \\
{[8.87 \mathrm{e}-03]^{\star * *}}\end{array}$ & & $\begin{array}{c}-3.30 \mathrm{e}-03 \\
{[5.70 \mathrm{e}-03]}\end{array}$ & & $\begin{array}{l}-3.00 \mathrm{e}-02 \\
{[5.19 \mathrm{e}-02]}\end{array}$ \\
\hline No. Of Persons a Member & & $\begin{array}{c}1.63 e-04 \\
{[2.33 e-04]}\end{array}$ & & $\begin{array}{c}2.32 \mathrm{e}-04 \\
{[1.05 \mathrm{e}-03]}\end{array}$ & & $\begin{array}{c}7.48 \mathrm{e}-04 \\
{[9.91 \mathrm{e}-04]}\end{array}$ & & $\begin{array}{c}2.68 \mathrm{e}-02 \\
{[1.20 \mathrm{e}-02]^{\star \star}}\end{array}$ \\
\hline House Ownership & & $\begin{array}{c}2.52 \mathrm{e}-03 \\
{[6.15 \mathrm{e}-04]^{\star \star *}}\end{array}$ & & $\begin{array}{c}1.05 \mathrm{e}-02 \\
{[3.07 \mathrm{e}-03]^{\star \star *}}\end{array}$ & & $\begin{array}{c}1.18 \mathrm{e}-04 \\
{[3.55 \mathrm{e}-03]}\end{array}$ & & $\begin{array}{c}7.31 \mathrm{e}-02 \\
{[3.35 \mathrm{e}-02]^{\star *}}\end{array}$ \\
\hline Net change in A\&L & & $\begin{array}{c}1.39 \mathrm{e}-07 \\
{[2.59 \mathrm{e}-08]^{\star \star \star}}\end{array}$ & & $\begin{array}{l}-5.03 e-08 \\
{[8.15 e-08]}\end{array}$ & & $\begin{array}{c}1.51 \mathrm{e}-07 \\
{[8.72 \mathrm{e}-08]^{*}}\end{array}$ & & $\begin{array}{c}5.59 \mathrm{e}-07 \\
{[7.91 \mathrm{e}-07]}\end{array}$ \\
\hline Constant & $\begin{array}{c}-6.36 \mathrm{e}-01 \\
{[1.95 \mathrm{e}-01]^{\star * *}}\end{array}$ & $\begin{array}{c}-2.95 e-01 \\
{[1.88 \mathrm{e}-01]}\end{array}$ & $\begin{array}{c}1.52 \mathrm{e}-01 \\
{[9.90 \mathrm{e}-01]} \\
\end{array}$ & $\begin{array}{c}8.08 \mathrm{e}-01 \\
{[1.04 \mathrm{e}+00]} \\
\end{array}$ & $\begin{array}{c}-2.83 e+00 \\
{[1.66 e+00]^{\star}}\end{array}$ & $\begin{array}{c}-2.13 e+00 \\
{[1.49 e+00]}\end{array}$ & $\begin{array}{l}-5.72 E+00 \\
{[5.68 \mathrm{e}+00]} \\
\end{array}$ & $\begin{array}{r}-4.10 e+00 \\
{[5.35 e+00]} \\
\end{array}$ \\
\hline Observations & 13970 & 13970 & 1176 & 1176 & 632 & 632 & 632 & 632 \\
\hline R-squared & 0.02 & 0.11 & 0.02 & 0.08 & 0.07 & 0.17 & 0.11 & 0.18 \\
\hline
\end{tabular}

